\title{
Responsabilidad extracontractual del contratista por los daños causado a terceros en la ejecución del contrato
}

\author{
Francisca Villalba Pérez \\ Profesa Titular de Derecho Administrativo \\ Universidad de Granada
}

\begin{abstract}
Sumario: I. INTRODUCCIÓN. II. EVOLUCIÓN NORMATIVA. III. REGULACIÓN ACTUAL. IV. CUESTIONES QUE SUSCITAN EL RÉGIMEN APLICABLE DE RESPONSABILIDAD EXTRACONTRACTUAL DEL CONTRATISTA. V. ASPECTOS SUSTANTIVOS. VI. PROCEDIMIENTO PARA EXIGIR LA RESPONSABILIDAD. VII. JURISDICCIÓN COMPETENTE. VIII. BREVE REFLEXIÓN SOBRE LOS CONTRATOS DE SEGURO Y LA RESPONSABILIDAD PATRIMONIAL DE LA ADMINISTRACIÓN PÚBLICA. IX. CONCLUSIONES.
\end{abstract}

\section{INTRODUCCIÓN}

La Ley de Expropiación Forzosa de 16 de diciembre de 1954 (en adelante LEF), y el Reglamento General de Contratos del Estado de 25 de noviembre de 1975 (en adelante RGCE), atribuían respectivamente al concesionario y contratista la responsabilidad por los daños causados durante la ejecución del contrato, salvo que el daño hubiese tenido su origen en una cláusula impuesta por la Administración de ineludible cumplimiento para el contratista. El procedimiento para reclamar era un procedimiento administrativo en el que la solicitud se dirigía a la Administración que otorgó la concesión, la cual de forma imperativa debía pronunciarse sobre la procedencia de la indemnización, quién debía pagarla y sobre la cuantía de la misma. La resolución administrativa dejaba abierta la vía contenciosa-administrativa que podía ser utilizada por el tercero dañado o por el contratista. En esta regulación ${ }^{1}$, tanto si el daño era imputable a la Administración como si lo

\footnotetext{
${ }^{1}$ El régimen de responsabilidad extracontractual instaurado por la LEF necesitó tiempo para aquilatar los perfiles de la institución. A ello contribuyó los distintos regímenes establecidos por el artículo 41 de la LRJAE de 1957, según la naturaleza de las relaciones de la Administración, y la práctica judicial al no exigir siempre la responsabilidad de los contratistas por vía contencioso-administrativa. De hecho, en la mayoría de los casos, los terceros dañados demandaron conjuntamente al contratista y a la Administración ante la jurisdicción civil, que se consideró competente haciendo caso omiso a la LEF. Reiteradamente los tribunales civiles afirmaban que la responsabilidad de los contratistas al tratarse de sujetos privados sometidos al Derecho Civil quedaba atribuida al conocimiento de esta jurisdicción y a través del conocimiento de este tipo de litigios desarrollaron una doctrina jurisprudencial caracterizada: $1^{\circ}$ ) por aplicar el criterio de la culpa, aunque en ocasiones se haya introducido una cierta objetivación; $2^{\circ}$ ) por considerar que el carácter de servicio público de la actividad y la titularidad del mismo que corresponde siempre a la Admi-
} 
era al contratista, la decisión sobre la exigencia de responsabilidad se encomendaba a la Administración, a través del procedimiento administrativo de responsabilidad, sin perjuicio de que su resolución fuera después controlada por la jurisdicción contencioso-administrativa.

Sin embargo, el artículo 98 de la Ley 13/1995, de 18 de mayo, de Contratos de las Administraciones Públicas (en adelante LCAP) ${ }^{2}$ consideró potestativo el requerimiento previo al órgano de contratación por el tercero dañado; limitó sus facultades al exclusivo pronunciamiento sobre la procedencia u origen de la responsabilidad; determinó que la reclamación se formulará conforme al procedimiento establecido en la legislación aplicable en cada supuesto; y residenció, en el caso de que la responsabilidad fuese imputable al contratista, su conocimiento en la jurisdicción civil. El contenido de este precepto pasó a formar parte del artículo 97 del Texto Refundido de la Ley de Contratos de las Administraciones Públicas, Real Decreto Legislativo 2/2000, de 16 de junio (en adelante TRLCAP) con una pequeña matización, la supresión del término «civil» al especificar

nistración, incluso cuando no lo gestiona directamente, determina que ésta sea responsable de su funcionamiento siempre que los daños que se produzcan sean consecuencia de una «culpa in vigilando»; $3^{\circ}$ ) que la responsabilidad entre el concesionario y la Administración, cuando ésta haya contribuido a la producción del daño, es solidaria. Este régimen no coincidía en modo alguno con el propugnado por la doctrina administrativa y por los tribunales contencioso-administrativos, aunque entre ellos tampoco existió unanimidad en la interpretación de los preceptos relativos a la responsabilidad de los contratistas y concesionarios. Véase R. BOCANEGRA SIERRA, «Responsabilidad de contratistas y concesionarios de la Administración Pública por los daños causados a terceros», REDA, n. ${ }^{\circ} 18,1978$, p. 308, donde se describe la situación de incertidumbre creada; J. Legina Villa y E. DesDENTADO, www.iustel.com, «La responsabilidad de los contratistas y concesionarios de servicios públicos».

2 A diferencia de la Ley de Contratos del Estado de 1965, la LCAP dedica un precepto específico al tema de la responsabilidad por daños producidos a terceros con ocasión de la ejecución de los contratos administrativos (artículo 98). Dicho precepto, al estar ubicado en la parte general de la materia (Libro I), será de aplicación a todos los contratos administrativos. Sin embargo, a pesar de que el apartado $3^{\circ}$ del artículo 98 de la LCAP señalaba que el requerimiento previo al órgano de contratación interrumpía la acción civil, no abordaba expresamente el tema de la jurisdicción competente para conocer de las reclamaciones de responsabilidad con ocasión de la ejecución de los contratos administrativos, a diferencia de la LEF que inequívocamente aludía a la jurisdicción contencioso-administrativa. Sobre la LCAP de 1995 véanse, F. SOSA WAGNER y otros, Comentarios a la Ley de Contratos de las Administraciones Públicas, Cedecs, Barcelona, 1995, p. 85; E. GarCíATREVIJANO, «Ejecución de los contratos administrativos: especial referencia a la ejecución y extinción del contrato de obras» en Derecho de los contratos públicos, obra colectiva dirigida por B. Pendas García, Praxis, Barcelona, 1995, p. 547; J. SuAY Rincón, «La ejecución del contrato administrativo. La cesión y la subcontratación» en Comentarios a la Ley de Contratos de las Administraciones Públicas, Civitas, Madrid, 1996, p. 415; F. CASTILlo BlANCO, «Consideraciones generales en torno a la ejecución del contrato administrativo en la reciente Ley de Contratos de las Administraciones Públicas», en Estudios sobre la contratación de las Administraciones Públicas, Comares, Granada, 1996, pp. 292 y ss; A. Ballesteros FernándeZ y otros, Contratos de las Administraciones Públicas, El Consultor, Madrid, 1995; Gómez-Ferrer Morant y otros, Comentarios a la Ley de Contratos de las Administraciones Públicas, Civitas, Madrid, 1996. 
que el requerimiento previo interrumpe el plazo de prescripción de la acción ${ }^{3}$.

Este cambio en la legislación contractual supuso el establecimiento de un sistema dual en materia de responsabilidad por daños causados por el funcionamiento de un servicio público en función del sujeto responsable. Si el daño es imputable a la Administración contratante, la responsabilidad será administrativa u objetiva por daños, el procedimiento administrativo y la jurisdicción competente será la contencioso-administrativa; si el daño es imputable al contratista habrá que instar dicha reclamación conforme a la legislación civil y ante los tribunales de ese orden ${ }^{4}$.

Esta dualidad de sistemas y regímenes jurídicos, civil y administrativo, según el sujeto responsable, puede generar disfunciones y, en algunos casos, falta de justicia material, pues, puede darse el caso de que el daño causado a un mismo sujeto a través de una misma actividad (gestionada igualmente por una misma empresa) pueda ser indemnizado si es imputable a la Administración y no indemnizado si lo es al contratista. Pero además, puede darse la situación de que si la resolución administrativa previa decide que el responsable es el contratista y esta resolución es impugnada en vía contencioso-administrativa por éste y a la vez en vía civil por el reclamante ¿no podrá determinar sendas sentencias contradictorias? ${ }^{5}$ ¿Por qué el tercero dañado ha de dirigirse previamente al órgano de contratación y no a la Administración titular del servicio si se trata de una res-

\footnotetext{
${ }^{3}$ Sobre el TRLCAP de 2000 pueden consultarse, entre otros, J.A. MoRENO MolinA, Nuevo régimen de contratación administrativa, comentarios al TRLCAP tras el RD Leg. 2/2000, de 16 de junio, La Ley, Madrid, 2001. Esta obra recoge una amplia recopilación de pronunciamientos jurisprudenciales en esta materia; A. BALlesteros FernÁNDEZ, Contratos de las Administraciones Públicas (Comentarios al Texto Refundido de la Ley), El Consultor, Madrid, 2000; R. GARCíA MaCho (dir), Comentarios a la Ley de Contratos de las Administraciones Públicas, Tirant lo blanch, Valencia, 2003; J.M. Gimeno Feliu (Coord), Contratación de las Administraciones Públicas: Análisis práctico de la nueva normativa sobre contratación pública, Atelier, Barcelona, 2004; G. ARIÑo OrTIZ, Comentarios al Texto Refundido de la Ley de Contratos de las Administraciones Públicas, Comares, Granada, 2004.

${ }^{4}$ Como posteriormente tendremos ocasión de ver, la modificación llevada a cabo por la legislación contractual no supone solo diferencias de matiz, sino que implica un cambio cualitativo y trascendental en su propia concepción, lo que arroja importantes consecuencias en todas y cada una de las cuestiones fundamentales implicadas. Véase C. HoRguE BAENA, «La responsabilidad del contratista por daños causados a terceros en la ejecución de los contratos administrativos», RAP, n. ${ }^{\circ} 147$, 1998, p. 354.

5 Para acabar con el gráficamente denominado «lamentable peregrinaje jurisdiccional», la STS de 19 de enero de 2005 declara la necesaria unificación jurisdiccional en esta materia: «ante la insostenible realidad de que reclamaciones idénticas, o sustancialmente iguales puedan ser resueltas de forma indistinta por los órdenes jurisdiccionales civil, administrativo y social» (Sala 3 ${ }^{\text {a }}$, Ponente Doña Margarita Robles Fernández).
} 
ponsabilidad extracontractual contraída en el ejercicio de una actividad que es competencia de la Administración pública? ¿El procedimiento establecido en el artículo 97 TRLCAP sería también aplicable a los contratos privados que celebre la Administración pública?

Para evitar estos y otros muchos problemas, al tratarse de una actividad de carácter administrativo cuya titular es la Administración pública y para hacer efectivos los derechos y garantías de los ciudadanos constitucionalmente reconocidos, el tercero dañado debería dirigir su solicitud a la Administración titular a través del procedimiento administrativo de responsabilidad patrimonial y posteriormente, si la responsabilidad le es imputable exclusivamente al contratista, la Administración deberá ejercer su acción de regreso frente a al patrimonio del contratista haciendo valer la intensa relación que les une. Esta postura cuenta hoy con mayor apoyo legal después de la reforma del artículo 9.4 LOPJ llevada a cabo por la Ley Orgánica 19/2003, de 23 de diciembre, que intenta remediar en parte esta situación atribuyendo a la jurisdicción contencioso-administrativa el conocimiento de las demandas de responsabilidad si se dirigen, además, contra las personas o entidades públicas o privadas indirectamente responsables de aquéllas ${ }^{6}$.

Estoy plenamente de acuerdo con la postura doctrinal que mantiene y defiende que la Administración no deberá convertirse en pagadora universal de responsabilidades privadas, por supuesto que no, deberá ser el contratista quien responda de sus propios actos durante la ejecución del contrato $^{7}$. Pero, también creo que el tercero dañado por el funcionamien-

${ }^{6}$ El artículo 9 apartado $4^{\circ}$ de la LOPJ después de la modificación llevada a cabo por Ley Orgánica 19/2003, de 23 de diciembre, ha quedado redactado de la siguiente forma:

Los tribunales del «orden contencioso-administrativo conocerán de las pretensiones que se deduzcan en relación con la actuación de las Administraciones Públicas sujeta al Derecho Administrativo, con las disposiciones generales de rango inferior a la Ley y con los reales decretos legislativos en los términos previstos en el artículo 82.6 de la Constitución, de conformidad con lo que establezca la Ley de esa jurisdicción. También conocerán de los recursos contra la inactividad de la Administración y contra sus actuaciones materiales que constituyan vía de hecho».

«Conocerán, asimismo, de las pretensiones que se deduzcan en relación con la responsabilidad patrimonial de las Administraciones públicas y del personal a su servicio, cualquiera que sea la naturaleza de la actividad o el tipo de relación de que se derive. Si a la producción hubieran concurrido sujetos privados, el demandante deducirá también frente a ellos su pretensión ante este orden jurisdiccional. Igualmente conocerán de las reclamaciones de responsabilidad cuando el interesado accione directamente contra la aseguradora de la Administración, junto a la Administración respectiva».

«También será competente este orden jurisdiccional si las demandas de responsabilidad patrimonial se dirigen, además, contra las personas o entidades públicas o privadas indirectamente responsables de aquéllas».

7 Entre otros, vid. R BOCANEGRA SIERRA, «Responsabilidad de contratistas y concesionarios de la Administración...», op. cit., p. 404; J. Leguina ViLlA, La responsabilidad civil de la Adminis- 
to normal o anormal de un servicio público gestionado indirectamente debería estar protegido en sus derechos por las garantías que proporciona el procedimiento administrativo de responsabilidad y la jurisdicción contencioso administrativa, por lo que debería dirigir su pretensión ante la Administración titular del servicio ${ }^{8}$, igual que cuando el servicio es gestionado directamente por la propia Administración titular.

La Administración en el ejercicio de su potestad autoorganizatoria: gestionar directa o indirectamente un servicio público, no podrá dejar sin contenido determinados preceptos constitucionales (artículo 106.2 CE) redactados precisamente para cubrir los daños o perjuicios ocasionados a los ciudadanos por el funcionamiento normal o anormal de un servicio público sin tener en cuenta el sujeto que los presta. El artículo 106.2 CE está redactado en clave del particular que sufre el daño como consecuencia del funcionamiento del servicio público y no del sujeto responsable, atiende directamente al derecho de los particulares a obtener una indemnización por toda lesión que sea consecuencia del funcionamiento de un servicio público y no distingue su gestión ${ }^{9}$. Parece claro que la voluntad del constituyente no era

tración pública, Tecnos, Madrid, 1984, p. 325; J. Leguina Villa y E. Desdentado Daroca, «Las acciones en materia de responsabilidad de la Administración pública: la responsabilidad de los contratistas y concesionarios de servicios públicos», www.iustel.com; E. GARCíA DE ENTERRíA y T.R. FERnÁndez Rodríguez, Curso de Derecho Administrativo, t. II, Civitas, Madrid, p. 384; R. GómeZFERrer Morant, «En torno a la Ley de Autopistas de Peaje», RAP, n. ${ }^{\circ} 68,1972$, p. 334; L. MarTín ReBOLlo, «La responsabilidad patrimonial de la Administración Local» en Tratado de Derecho Municipal, obra colectiva dirigida por S. MuÑOZ MACHADO, vol. I, Civitas, Madrid, p. 618; en la misma obra, J.F. Mestre DeLGADO, «Las formas de prestación de los servicios públicos locales. En particular, la concesión», p. 1259 en la edición de 1988, véase también la edición publicada en 2003; J. GonzÁlez Pérez, Responsabilidad patrimonial de las Administraciones Públicas, Civitas, Madrid, 1996, p. 180; S. MuÑOZ MACHADO, La responsabilidad civil concurrente de las Administraciones Públicas, Civitas, Madrid, 1992 p. 135. Lo más que proponen algunos de estos autores (S. MUÑOZ MACHADO) es que la Administración sea la garante última de la indemnización, lo cual se conseguiría por la vía de la responsabilidad subsidiaria de ésta en el caso de insolvencia del concesionario o contratista.

${ }^{8}$ Conviene advertir, como ya apuntara G. GARCía ÁlvarEZ que en estos casos más que establecer una responsabilidad directa de la Administración, lo que se le atribuye es una posición de garante de la indemnidad patrimonial del tercero dañado con ocasión del funcionamiento de una actividad de carácter público de la que es titular («Responsabilidad patrimonial de los poderes públicos» en Derecho Administrativo. Parte especial, obra colectiva coordinada por J. Bermejo Vera, Civitas, Madrid, 1999, p. 953); Véanse también F. GonZÁlez NAVARRo, «Responsabilidad de la Administración por daños causados a terceros por el empresario de un servicio público», $R D A F, \mathrm{n} .^{\circ}$ 44-45, 1976, pp. 215 a 250; G. ARIÑo ORTIZ, «El servicio público como alternativa», REDA, n. ${ }^{\circ} 23,1979$, p. 552; P. TORRENT I RIBERT, La responsabilidad patrimonial de las Administraciones Públicas, Madrid, 1995, p. 7; R. JuRISTO SÁNCHEZ, La ejecución del contrato de obra pública, Madrid, 1983, p. 166.

${ }^{9}$ Esta es la razón por la que cierta doctrina propugna que debe mantenerse, cuando menos, que el régimen sustantivo de responsabilidad ante terceros por daños en la ejecución de los contratos- 
dejar fuera de la responsabilidad patrimonial pública los servicios públicos gestionado de forma indirecta. Una decisión administrativa como la de organizar los servicios públicos no puede determinar una minoración de derechos constitucionalmente reconocidos y garantizados.

Y todo ello sucede a pesar de la artillería legal aprobada a favor de la unificación del régimen sustantivo procedimental y jurisdiccional de la responsabilidad patrimonial de la Administración pública. Reforma iniciada por la Ley 30/1992, seguida posteriormente por la LJCA de 1998, la LOPJ para adecuar su contenido al de la nueva LJCA y, por último, por la Ley 4/1999, que modifica en esta materia a la Ley $30 / 1992^{10}$. ¿Qué ha sucedido entonces?, simplemente que el legislador optó por un criterio subjetivo basado exclusivamente en la naturaleza del sujeto a quien se le imputa la responsabilidad y no por la naturaleza de la actividad generadora del daño: un servicio público de la competencia de una Administración pública.

Otro tanto ha venido sucediendo hasta ahora cuando la Administración cubría los riesgos de sus servicios a través de un contrato de seguro pri-

administrativos y, sobre todo, en la gestión de los servicios públicos sea idéntico tanto si son imputables a la Administración como si lo son al contratista. En tales términos, es posible mantener tanto que el régimen objetivo de responsabilidad establecido constitucionalmente es propio de la Administración pública como sostener que deriva del servicio público con independencia de quién lo esté gestionando. En definitiva, defender tanto una noción subjetiva-orgánica como material-funcional de la noción deservicio público a efectos de responsabilidad. vid. Entre otros, J. SUAY RinCóN, «Ejecución del contrato administrativo. La cesión del contrato y la subcontratación» en Comentarios a la Ley de Contratos de las Administraciones Públicas, Civitas, Madrid, 1996, p. 415; J. Corella Pla, Contratación Pública, vol. II, en VV.AA., Marcial Pons, Madrid, 1997, p. 182; M. BeLAdiez Rojo, Responsabilidad e imputación de daños por el funcionamiento de los servicios públicos, Tecnos, Madrid, 1997, p. 264.

${ }^{10}$ El primer intento de unificación del régimen sustantivo, procedimental y jurisdiccional de la responsabilidad patrimonial de la Administración pública se concretó en la Ley 30/1992, de 26 de noviembre, que pretendió instaurar un régimen único y general para todas las Administraciones públicas y todas sus actividades. Sin embargo, su aplicación no disipó por completo las dudas sobre la pretendida unificación ni alteró la práctica de los operadores jurídicos, éstas dudas no quedaron totalmente despejadas hasta los años 1998-1999 con la aprobación de la Ley 29/1998, de 13 de julio, de la Jurisdicción Contencioso-Administrativa (LJCA), las modificaciones de la Ley Orgánica del Poder Judicial (LOPJ) para adecuar su contenido al de la LJCA y las introducidas por Ley 4/1999, de 13 de enero, que de manera definitiva intentaron consagrar la unificación del régimen sustantivo (sistema de responsabilidad objetiva) y de régimen jurisdiccional (la reclamación por responsabilidad a la Administración se ventilará necesariamente y en todo caso ante la jurisdicción contencioso-administrativa, después de un previo pronunciamiento de la Administración). La última reforma llevada a cabo con la intención de intensificar y dejar clara de una vez por todas la pretendida unificación sustantiva y jurisdiccional de la responsabilidad patrimonial de las Administraciones pública ha sido introducida por la Ley Orgánica 19/2003. Véanse La responsabilidad patrimonial de las Administraciones Públicas, Ponencia Especial de Estudios del Consejo de Estado (ponente: D. BlANQUER), INAP, Madrid, 1997, p. 146; F. PANTALEÓN, «Responsabilidad patrimonial de las Administraciones públicas: sobre la jurisdicción competente», REDA, n. ${ }^{\circ} 91,1996$, pp. 403 a 413. 
vado. Entre los artículos de la Ley 30/1992 que regulan la responsabilidad patrimonial de las Administraciones públicas y la Ley 50/1980, de 8 de octubre, del Contrato de Seguro (en adelante LCS), existen evidentes contradicciones ${ }^{11}$. La LCS desdibuja el carácter directo de la responsabilidad de la Administración al atribuir al particular dañado una acción civil directa contra la compañía aseguradora (artículo 76), y matiza el carácter preceptivo de la Ley 30/1992 en cuanto a la obligación por parte de la Administración de repercutir la indemnización pagada a sus funcionarios cuando éstos hubiesen actuado de forma dolosa o con culpa grave (artículo 43) ${ }^{12}$.

A paliar algunas de estas contradicciones va dirigida la reforma de los artículos 9.4 LOPJ y 2.e de la LJCA, llevada a cabo por la Ley Orgánica 19/2003, que posibilita al tercero dañado acudir a la jurisdicción contencioso-administrativa cuando la Administración cuente con un seguro de responsabilidad, $\mathrm{y}$ le atribuye también a esta jurisdicción el conocimiento de las reclamaciones de responsabilidad cuando el interesado accione directamente contra la aseguradora y la Administración respectiva ${ }^{13}$.

${ }^{11}$ La Dirección General de Seguros a través de la Resolución de 26 de junio de 1996 prohibió a las Administración pública celebrar contratos de seguros para cubrir su responsabilidad patrimonial. En el texto de la mencionada resolución, fruto de una consulta elevada por una compañía de contratos de seguros privada, la Dirección General evidenciaba las manifiestas contradicciones existentes entre la Ley 30/1992 y la LCS de 1980 que imposibilitaban a la Administración la suscripción de contratos privados de seguros sobre responsabilidad patrimonial mientras no existiese una regulación específica de este tipo de contratos. El texto de la Resolución está publicado en la Revista de Derecho de los Seguros Privados, mayo-junio 1997, pp. 28 y ss., así como en M.J. Montoro Chiner y M.C. Hill Prados, Responsabilidad patrimonial de la Administración y contrato de seguro, Atelier, Barcelona, 2002, pp. 121 y ss y E. GAMERO CASADO, «Los contratos de seguro de responsabilidad extracontractual de las Administraciones Públicas», REDA, n. ${ }^{\circ} 103,1999$, pp. 357-381; J.E. SoRIANO, «Asunto Biet Bernal: un pequeño arrêt Blanco en nuestra justicia. ¿Vuelta de la responsabilidad de la Administración a la jurisdicción civil?», REDA 115, 2002, pp. 399-404; A. HUERGO LORAS, «El seguro de responsabilidad civil de las Administraciones Públicas y la doctrina de la "vis atractivas"», REDA 122, 2004, pp. 199-222.

12 El artículo 43 de la LCS permite la subrogación de la compañía aseguradora para dirigirse frente a aquellos funcionarios que hubiesen obrado de forma dolosa pero no cuando lo hayan hecho a través de una actuación culposa. En este último supuesto, el funcionario que hubiese actuado con culpa grave y la Administración haya cubierto sus servicios a través de un contrato de seguro se encontraría en una situación de impunidad carente de toda justificación que podría suponer una manifiesta desigualdad respecto del funcionario cuya Administración no haya cubierto sus servicios que sí se vería obligado a responder.

13 Además de la reforma llevada a cabo del artículo 9.4 de la LOPJ, la disposición adicional decimocuarta de Ley 19/2003, de 23 de diciembre, introduce también una pequeña modificación en el artículo 2.e de la LJCA para adecuar su contenido al del nuevo artículo 9.4 de la LOPJ. Quedando el artículo 2.e de la LJCA redactado de la siguiente forma: «La jurisdicción contencioso-administrativa conocerá de la responsabilidad patrimonial de las Administraciones públicas, cualquiera que sea la naturaleza de la actividad o el tipo de relación de que derive, no pudiendo ser demandadas aquellas por este motivo ante los órdenes jurisdiccionales civil o social, aun cuando en la producción del daño concurran con particulares o cuenten con un seguro de responsabilidad». 


\section{EVOLUCIÓN NORMATIVA}

Antes de adentrarnos en los problemas que plantea la aplicación del régimen de responsabilidad extracontractual del contratista debemos aclarar una cuestión previa sobre el objeto de este trabajo. Cuando el contratista produce un daño a terceros en la ejecución del contrato como consecuencia de una orden o mandato de la Administración contratante, o cuando el daño es provocado por los vicios del proyecto elaborado por ésta, la normativa vigente determina que se trata de una responsabilidad patrimonial de la Administración exigible de acuerdo con las reglas y criterios señalados en los artículos 139 y siguientes de la Ley 30/1992. Su regulación ${ }^{14} \mathrm{e}$ interpretación es clara y precisa, no genera mayores problemas, sin embargo, cuando el daño es causado a un tercero sin mediar orden ni mandato por parte de la Administración y sin tener su origen en los vicios de un proyecto, es decir, cuando es imputable exclusivamente al contratista, la situación presenta mayores dificultades. A este último tipo de responsabilidad dedicaremos exclusivamente nuestro objeto de estudio.

La responsabilidad extracontractual de los concesionarios y contratistas por los daños causados a terceros en la ejecución del contrato hasta 1954 estaba sometida al Código Civil. Se consideraba una responsabilidad entre particulares basada en el principio de culpa y en caso de conflicto conocían los tribunales civiles.

La situación cambió con la LEF que después de proclamar en el artículo 121 apartado $1^{\circ}$ el principio general de responsabilidad patrimonial de

14 J. Leguina Villa, La responsabilidad civil de la Administración pública, Tecnos, Madrid, 1983; A. Blasco Esteve, La responsabilidad patrimonial por actos administrativos, Civitas, Madrid, 1981; E. GARCíA DE ENTERRÍA, Los principios de la nueva Ley de Expropiación Forzosa, Civitas, Madrid, 1983; F. GONZÁLEZ NAVARRO, «Responsabilidad de la Administración por daños causados a terceros por el empresario de un servicio público», $R D A F$, n. ${ }^{\circ} 44-45,1976$; S. MuÑOZ MACHADO, La responsabilidad civil concurrente de las Administraciones públicas, Civitas, Madrid, 1992, edición ampliada en 1998; M. BELADIEZ, Responsabilidad e imputación de daños por el funcionamiento de los servicios públicos, Tecnos, Madrid, 1997; J.A. Mestre Delgado, «Las formas de prestación de los servicios públicos locales. En particular la concesión» en S. MUÑOZ MACHADO (dir.) Tratado de Derecho Municipal, t. II, Civitas, Madrid, 2003; L. Martín Rebollo, «La responsabilidad de las Administraciones públicas» en Gobierno y Administración en la Constitución, vol. I, IEF, Madrid, 1988; M. Rebollo Puig, «Servicios públicos concedidos y responsabilidad de la Administración: imputación o responsabilidad por hecho de otro», Revista Poder Judicial n. ${ }^{\circ} 20$, 1990; J.L GIL IBAÑEZ, La responsabilidad patrimonial de los poderes públicos, Actualidad Editorial, Madrid, 1994; P. TORRENT I RIBERT, La responsabilidad patrimonial de las Administraciones Públicas, Madrid, 1995; G. GARCía ÁlvareZ, «La responsabilidad patrimonial de los poderes públicos» en Derecho Administrativo. Parte especial, obra colectiva coordinada por J. BERMEJo VerA, Civitas, Madrid, 1999; F. PANTALEÓN PRIETO, «Responsabilidad de las Administraciones públicas: sobre la jurisdicción competente», REDA, n. ${ }^{\circ} 91,1996$. 
la Administración: «dará lugar a indemnización toda lesión que los particulares sufran en sus bienes y derechos como consecuencia del funcionamiento normal o anormal de los servicios públicos», concretó en el apartado $2^{\circ}$ la responsabilidad del concesionario por los daños producidos a terceros en la ejecución del contrato: «en los servicios públicos concedidos la indemnización correrá a cargo del concesionario, salvo que el daño tenga su origen en alguna cláusula impuesta por la Administración y sea de ineludible cumplimiento para el concesionario».

El procedimiento para reclamar la responsabilidad venía recogido en el artículo $123 \mathrm{LEF}$ donde se exigía que la solicitud se dirigiera a la Administración que otorgó la concesión, la cual resolvía, tanto sobre la procedencia de la indemnización y su cuantía, como quién debía pagarla. La resolución de la Administración dejaba abierta la vía contencioso-administrativa que podía ser utilizada por el particular o el concesionario. Posteriormente, el Reglamento de Expropiación Forzosa de 1957 (en adelante REF) en los artículos 134 a 137 regulaba con mayor detalle el procedimiento a seguir ${ }^{15}$.

Como vemos la LEF regulaba de forma muy completa la responsabilidad del concesionario pero llamaba la atención que esa normativa no contemplara la responsabilidad del contratista en general y en concreto del contratista de obra pública ${ }^{16}$.

\footnotetext{
${ }^{15}$ Sobre el régimen de responsabilidad extracontractual de concesionarios y contratistas derivado de la LEF, pueden verse los trabajos de R. BocANEGRA SieRRA, «La responsabilidad civil de los concesionarios y contratistas de la Administración por daños causados a terceros», Documentación Administrativa, n. ${ }^{\circ} 237-238$, pp. 206 y 207; del mismo autor y con el mismo título, REDA, n. ${ }^{\circ} 18$, 1978, p. 308; E. RIVERO ISERN, El Derecho Administrativo y las relaciones entre particulares, Instituto García Oviedo, Sevilla, 1969, pp. 218-219, que señalaba al orden contencioso-administrativo como la jurisdicción competente para conocer los litigios ocasionados entre concesionarios de obras públicas y terceros perjudicados antes de la Ley de Obras Públicas de 1877; C. Horgue BaenA, «La responsabilidad del contratista por daños causados a terceros», $R A P$ n. ${ }^{\circ} 147,1998$, pp. 337-367; F. RODRIGO MORENO, «La responsabilidad patrimonial de la Administración y la civil extracontractual del contratista», El Consultor de los Ayuntamientos n. ${ }^{\circ} 2$, 2001, p. 250-254; P. LuIS SERRERA CONTRERAS, «La responsabilidad del contratista en la novísima legislación de contratos del Estado», $R A A P$, n. $^{\circ} 23$, pp. 11 a 21; J. Leguina Villa y E. Desdentado Daroca, «Las acciones en materia de responsabilidad de la Administración pública: La responsabilidad de los contratistas y concesionarios de servicios públicos», www.iustel.com.
}

${ }^{16}$ No quedó resuelto en esos momentos si el régimen de responsabilidad de los concesionarios era igualmente aplicable a todos los contratistas de la Administración o si lo que daba entrada a las previsiones de la LEF era la prestación del servicio público, habida cuenta que la Ley de Contratos del Estado de 1965 no lo había sancionado con carácter general para todos los contratos administrativos. Asimismo, las previsiones del artículo 134 del Reglamento General de Contratos del Estado de 1967 parecían mantener la responsabilidad extracontractual del contratista de obra pública en los estrictos términos de la responsabilidad civil entre particulares, tal como derivaba de la Ley de Obras Públicas de 1877, con la salvedad de imputarlos a la Administración cuando eran consecuen- 
Esa omisión fue subsanada por el artículo 134 del RGCE en los siguientes términos: Será de cuenta del contratista indemnizar todos los daños que cause a terceros como consecuencia de las operaciones que requiera la ejecución de las obras. Cuando tales daños hayan sido ocasionados como consecuencia inmediata y directa de una orden de la Administración, o de los vicios del proyecto, será ésta responsable dentro de los límites establecidos en la LRJAE. Las reclamaciones de los terceros se presentarán, en todo caso, en el término de un año ante el órgano de contratación que decidirá, oído el contratista, sobre la procedencia, su cuantía y la parte responsable. Contra la resolución del órgano de contratación podrá interponerse recurso ante la jurisdicción contencioso-administrativa.

Como podemos apreciar el RGCE recoge para el contratista el sistema instaurado en la LEF para los concesionarios. En ambos supuestos la decisión sobre la exigencia de responsabilidad se encomendaba a la Administración, sin perjuicio de que su resolución fuera después controlada por la jurisdicción contencioso-administrativa. Normativamente el sistema quedó bastante aquilatado.

Sin embargo, donde más clara era la competencia del legislador estatal para establecer una regulación unitaria en esta materia, la Ley 30/1992 ${ }^{17}$, de forma un poco sorprendente guardó silencio sobre la responsabilidad del contratista. Silencio roto, en parte, posteriormente por el Reglamento de Procedimiento de Responsabilidad Patrimonial de las Administraciones Públicas, Real Decreto 429/1993, de 26 de marzo (en adelante RRP), que en el artículo 1 apartado $3^{\circ}$, dedicado al ámbito de aplicación, señala: «Se seguirán los procedimientos previstos en los capítulos II y III de este Reglamento para determinar la responsabilidad de las Administraciones

cia de vicios del proyecto o de órdenes dadas por ésta. De todas formas, poco a poco, el régimen de responsabilidad extracontractual de los concesionarios de servicios públicos se extenderá a los contratistas de obras públicas mediante la interpretación de que la noción de servicio público era comprensiva de toda la actividad de titularidad administrativa y que el concesionario era utilizado por la Administración como una figura interpuesta para el desempeño de tal actividad. Véanse sobre este tema, los Dictámenes del Consejo de Estado 36913, de 18 de junio de 1970 y 38603, de 12 de julio de 1973. También, M. Clavero ARÉvalo, «La quiebra de la pretendida unidad jurisdiccional en materia de responsabilidad administrativa» $R A P$, n. $^{\circ} 66,1971$ y E. RIVERo ISERN, El Derecho Administrativo y las relaciones entre particulares, Instituto García Oviedo, Sevilla, 1969, pp. 241-242.

${ }^{17}$ El artículo 149.1.18 de la Constitución atribuye al Estado la legislación básica sobre contratos y concesiones administrativas y el sistema de responsabilidad de todas las Administraciones públicas. Como señala el profesor MARTín REBOLlo este apartado tiende a garantizar la unidad de lo que, junto con la jurisdicción contencioso-administrativa, podría considerarse el núcleo fundamental del Derecho administrativo general (Leyes Administrativas, Aranzadi, Pamplona, 2002, p. 169). Sobre la génesis de este precepto constitucional, véase M. CLAVERO ARÉVALO, «Las transformaciones del Derecho Administrativo», conferencia pronunciada en el INAP, Madrid, 2002, publicada en la página www.inap.es. 
públicas por los daños y perjuicios causados a terceros durante la ejecución del contrato, cuando sean consecuencia de una orden directa e inmediata de la Administración o de los vicios del proyecto elaborado por ella misma, con arreglo a la legislación de contratos de las Administraciones Públicas, sin perjuicio de las especialidades que, en su caso, dicha legislación establece. En todo caso se dará audiencia al contratista, notificándole cuantas actuaciones se realicen en el procedimiento, al efecto de que se persone en el mismo, exponga lo que a su derecho convenga y proponga cuantos medios de prueba estime necesarios»».

De la remisión expresa a la legislación de contratos realizada por el RRP de 1993 se deducía que seguían vigentes los artículos 121 a 123 de la LEF y 134 del RGCE, sin embargo, derogó expresamente los artículos 133 a 138 del REF.

Posteriormente, la LCAP de 1995 introduce por primera vez en la normativa contractual pública la responsabilidad por daños y perjuicios causados a terceros en la ejecución del contrato ${ }^{18}$, señalando en el artículo 98 apartado $1^{\circ}$ que: será obligación del contratista indemnizar todos los daños y perjuicios que se causen a terceros como consecuencia de las operaciones que requieran la ejecución del contrato ${ }^{19}$, remitiendo a la jurisdicción civil el conocimiento de las cuestiones que puedan suscitarse.

Si los daños hubiesen sido causados por los vicios del proyecto elaborado por el contratista, por defectos e insuficiencias técnicas, por errores materiales, omisiones e infracciones de preceptos legales o reglamentarios, el artículo 219 LCAP exige al contratista responder tanto frente a la Administración como frente a terceros. Por otra parte el artículo 162 LCAP, concretando las obligaciones del contratista en el contrato de gestión de servicios públicos,

\footnotetext{
${ }^{18}$ Hasta 1995 podía considerarse que seguían vigentes los artículos 121.2 y 123 de la LEF, puesto que éstos eran los únicos que regulaban la responsabilidad de los concesionarios. A partir de 1995 la regulación de la responsabilidad extracontractual del contratista en general se encuentra en la legislación de contratos de las Administraciones públicas y, por tanto, pueden considerarse implícitamente derogados los artículos de la LEF que se referían a ella.

19 Concreta el apartado $2^{\circ}$ del artículo 98 LCAP que cuando los daños hayan sido ocasionados como consecuencia inmediata y directa de una orden de la Administración, será ésta responsable dentro de los límites señalados en las leyes. También será la Administración responsable de los daños que se causen a terceros como consecuencia de los vicios del proyecto elaborado por ella misma en el contrato de obras o en el de suministro de fabricación. El apartado $3^{\circ}$ señala que los terceros podrán requerir previamente dentro del año siguiente a la producción del daño, al órgano de contratación, para que éste, oído el contratista, se pronuncie sobre cuál de las partes contratantes corresponde la responsabilidad por daños. El ejercicio de esta facultad interrumpe el plazo de prescripción de la acción civil. Por último, el apartado $4^{\circ}$ remite el procedimiento de la reclamación a lo establecido en la legislación aplicable en cada supuesto.
} 
especificó que deberá indemnizar los daños que se causen a terceros como consecuencia de las operaciones que requieran el desarrollo del servicio, excepto cuando el daño sea producido por causas imputables a la Administración. Finalmente, la DA $5^{\mathrm{a}}$ LCAP dispuso que la responsabilidad patrimonial de las autoridades y del personal al servicio de las Administraciones pública ${ }^{20}$ derivada de sus actuaciones en materia de contratación administrativa, tanto por los daños causados a particulares como a la propia Administración, se exigirá con arreglo a lo dispuesto en la Ley 30/1992 y en el RRP.

El contenido del artículo 98 de la LCAP pasó a formar parte del artículo 97 del TRLCAP con una pequeña matización, se suprime en el apartado $3^{\circ}$ el término civil para especificar que el requerimiento previo al órgano de contratación interrumpe el plazo de prescripción de la acción. Ahora se afirma que el «ejercicio de esta facultad interrumpe el plazo de prescripción de la acción» (a secas).

\section{REGULACIÓN ACTUAL DE LA RESPONSABILIDAD EXTRACONTRACTUAL DEL CONTRATISTA}

Con intención de clarificar el desarrollo de este epígrafe al tratarse de una materia que implica o afecta a distintos sectores normativos lo dividiremos en tres partes: a) normativa contractual; b) normativa sustantiva de responsabilidad patrimonial y c) normativa procesal.

\footnotetext{
${ }^{20}$ No debemos olvidar que este precepto se refiere a las «autoridades y al personal al servicio de las Administraciones públicas», y el contratista no está incluido ni en el concepto de autoridad ni tampoco en el de personal a su servicio. La integración en la organización administrativa del agente causante de la lesión al tercero se considerará, pues, el título básico de imputación. Desde esta perspectiva, los daños ocasionados por los concesionarios y contratistas no son, en principio, imputables a la Administración, al no estar integrados en la organización administrativa. Se entiende que lo están los funcionarios públicos, por supuesto, pero también los agentes ocasionales de la Administración, incluso las personas sometidas a tutela de la Administración. Esta concepción ha sido mayoritaria en la doctrina, al menos hasta la Ley 30/1992. En este sentido, vid. E. GARCÍA DE ENTERRíA y T.R. FERnÁNDEZ RodríGUEZ, Curso de Derecho Administrativo, II, Civitas, Madrid, ed. 1986, p. 345, también en la edición de 1998, vol. II, pp. 387-389; L. MARTín RETORTILLO, «Responsabilidad patrimonial de la Administración pública y jurisdicción», RAP n. ${ }^{\circ} 42,1963$, p. 187; L. MARTín REBOLLO, La responsabilidad patrimonial de la Administración en la jurisprudencia, Civitas, Madrid, 1973, y «la responsabilidad patrimonial de la Administración Local» en Tratado de Derecho Municipal, I, dirigido por S. MuÑOz MaCHADO, Civitas, Madrid, 1988, p. 604; J. Leguina Villa, La responsabilidad civil de la Administración Pública, Tecnos, Madrid, 1983, p. 324; L. Cosculluela Montaner, Manual de Derecho Administrativo, Civitas, Madrid, 1992, p. 447; más recientemente J. A. Moreno Molina, Nuevo régimen de contratación administrativa, comentarios al Texto Refundido de la Ley de Contratos de las Administraciones Públicas tras el Real Decreto Legislativo 2/2000, de 16 de junio, La Ley, Madrid, 2001, donde se recoge una amplia recopilación de sentencias judiciales sobre este tema; J. A. HERNÁNDEZ CORCHETE, «Comentario al artículo 97 del TRLCAP» en Comentarios a la Ley de Contratos de las Administraciones Públicas, dirigidos por R. GARCíA MACHO, Tirant lo blanch, Valencia, 2003, pp. 487-490.
} 


\section{a) Normativa contractual}

El artículo 97 apartado $1^{\circ}$ del TRLCAP dispone que será obligación del contratista indemnizar todos los daños y perjuicios que se causen a terceros como consecuencia de las operaciones que requiera la ejecución del contrato.

De este primer apartado debemos retener la expresión utilizada por el legislador: el contratista indemnizará «todos» ${ }^{21}$ los daños que cause a terceros, de la que podríamos deducir que no sólo serán los derivados de una actuación dolosa o culposa, por lo que a simple vista su responsabilidad extracontractual no debería regirse por el artículo 1902 del CC ni tener carácter subjetivo a pesar de tratarse de un sujeto privado.

El apartado $3^{\circ}$ concreta que los terceros podrán requerir previamente, dentro del año siguiente a la producción del hecho al órgano de contratación para que éste oído el contratista se pronuncie sobre a cual de las partes contratantes corresponde la responsabilidad de los daños. El ejercicio de esta acción interrumpe el plazo de la acción.

Por último el apartado $4^{\circ}$ del artículo 97 especifica que la reclamación se formulará, en todo caso conforme al procedimiento establecido de la legislación aplicable a cada supuesto.

Entre las obligaciones generales del gestor de servicios públicos, al artículo 161 TRLCAP concreta en su apartado c) que será obligación del contratista indemnizar los daños que se causen a terceros como consecuencia de las operaciones que requiera el desarrollo del servicio, excepto cuando el daño sea producido por causas imputables a la Administración ${ }^{22}$. En el ámbito del contrato de servicios, el artículo 211.2 del TRLCAP dispone que el contratista será responsable de la calidad técnica de los trabajos que desarrolle y de las prestaciones y servicios realizados, así como de las consecuencias que se deduzcan para la Administración o para terceros de las omisiones, errores, métodos inadecuados o conclusiones incorrectas en la ejecución del contrato ${ }^{23}$.

\footnotetext{
21 La cursiva y las comillas son mías.

22 La expresión, «causas imputables a la Administración», es más amplia que la de orden o mandato, por lo que la responsabilidad de la Administración puede derivarse también de una culpa in vigilando, es decir, de aquellos casos en que haya incumplido sus obligaciones de policía o inspección y ello contribuya a la producción del daño.

23 No debemos olvidar que la responsabilidad extracontractual del contratista se genera como consecuencia de la ejecución de un contrato administrativo nominado o típico (artículo 5.2.a TRLCAP) cuyo régimen jurídico remite íntegramente el artículo 7 TRLCAP al Derecho Administrativo. Estos contra-
} 
Por último, la Ley 13/2003, de 23 de mayo, Reguladora del Contrato de Concesión de Obra Públicas (artículo 243), reitera que será obligación del concesionario indemnizar los daños que ocasione a terceros en la ejecución de la obra o en su explotación, cuando le sean imputables de acuerdo con el artículo 97 del TRLCAP. Si el concesionario de obra pública contratase con terceros parte de la obra, será el responsable ante el órgano de contratación de las consecuencias derivadas de la ejecución o resolución de dicho contrato y también responsable único frente a éstos de las mismas consecuencias (artículo 238) ${ }^{24}$.

\section{b) Normativa sustantiva de responsabilidad patrimonial}

La responsabilidad patrimonial de las Administraciones públicas ha quedado plasmada en nuestro ordenamiento jurídico en el artículo 106.2 CE desarrollado posteriormente en los artículos 139 y siguientes y en la disposición adicional $12^{\text {a }}$ de la Ley 30/1992 así como en el RRP de 1993, con un objetivo claro, indemnizar los daños y perjuicios que los particulares sufran como consecuencia del funcionamiento normal o anormal del servicio público.

De los artículo 139 a 146 de la Ley 30/1992, dedicados a la responsabilidad patrimonial de las Administraciones públicas ${ }^{25}$, podemos deducir

tos -ejecución y concesión de obra pública, gestión de servicio público, suministro, consultoría y asistencia o servicios- están sometidos en cuanto a su preparación, adjudicación, efectos y extinción al TRLCAP y a sus disposiciones de desarrollo (Reglamento General de la Ley de Contratos de las Administraciones Públicas, Real Decreto 1098/2001, de 12 de octubre), supletoriamente a las restantes normas de Derecho Administrativo y, en su defecto, a las normas de Derecho privado.

${ }^{24}$ Una de las notas que caracterizan al contrato de concesión de obra pública es el riesgo que asume el contratista en la construcción, conservación y explotación de la obra pública. Sin embargo, la exposición de motivos de la Ley 13/2003, de 23 de mayo, mitiga algo esta obligación reconociendo que: «en un contrato de larga duración, la asunción del riesgo, ante la imposibilidad de predecir con un margen razonable de error el futuro, no puede transformar el contrato en un negocio aleatorio por lo que en coherencia se impone moderar adecuadamente los límites del riesgo, si se quiere atraer la participación del capital y la iniciativa privada en inversiones cuyo volumen exige el esfuerzo compartido de los sectores público y privado». A pesar de ello la asunción de riesgos en proporción sustancial por el concesionario resulta determinante para que el contrato de concesión merezca tal calificación». Véanse las conclusiones de la Comunicación Interpretativa 2000/C 121/02 de la Comisión Europea, publicada en el DOCE de 29 de abril de 2000.

${ }^{25}$ El régimen de responsabilidad que contiene la Ley 30/1992 obedece a los siguientes principios: Es un régimen unitario que rige para todas las Administraciones públicas; es un régimen general que abarca toda la actuación administrativa, por acción u omisión; directo, la Administración responde por los daños anónimos a ella imputables pero cubre también de forma directa y no sólo subsidiaria, la eventual acción dañosa de sus empleados; una responsabilidad objetiva que pivota sobre la idea de lesión y no sobre la de culpa; de reparación integral, cubre todos los daños, aunque, claro está, su reclamación está sometida a un plazo de prescripción de un año y responde al principio de unidad jurisdiccional en el orden contencioso-administrativo. 
una clara intención del legislador por unificar esta materia a través de una triple vía:

$\left.1^{a}\right)$ Unificación del régimen jurídico aplicable;

$\left.2^{a}\right)$ Unificación del procedimiento de la reclamación de indemnización;

$\left.3^{a}\right)$ Unificación de la jurisdicción competente.

La unificación del régimen aplicable se encuentra recogida en el artículo 145.1 al disponer que para hacer efectiva la responsabilidad patrimonial los particulares exigirán directamente a la Administración las indemnizaciones por los daños y perjuicios causados por las autoridades y personal a su servicio, siendo indiferente la naturaleza pública o privada de la prestación, según establece el artículo 142.6. El artículo 144 deja claro el carácter directo de la responsabilidad de las Administraciones públicas cuando actúen en relaciones de derecho privado ${ }^{26}$.

El procedimiento a seguir para la reclamación de daños viene establecido en los artículos 142 y 143 de la Ley 30/1992 así como en el artículo 1.3 del RD 429/1993.

Por último, se unifica en la jurisdicción contencioso-administrativa el conocimiento de las cuestiones que puedan suscitarse en materia de responsabilidad patrimonial de las Administraciones públicas. Unidad que había introducido el artículo 3 b) de la LJCA de 1956, pero que rompió el artículo 41 de la LRJAE de 1957, al atribuir la competencia a la jurisdicción civil cuando el «Estado actúe en relaciones de Derecho privado». Esta unificación jurisdiccional en el orden contencioso-administrativo va dirigida no sólo a la responsabilidad patrimonial de las Administraciones públicas, sino que la disposición adicional $12^{\mathrm{a}}$ de la Ley 30/1992 -introducida por Ley 4/1999 de 13 de enero-, atribuye también el conocimiento a la jurisdicción contencioso-administrativa de las reclamaciones de responsabilidad patrimonial que puedan exigirse a los centros privados concertados con las Entidades Gestoras de la Seguri-

\footnotetext{
${ }^{26}$ El artículo 144 de la Ley 30/1992 regula la responsabilidad de las Administraciones públicas cuando actúen sometidas al Derecho privado, determinando que responderán directamente de los daños y perjuicios causados por el personal que se encuentre a su servicio, considerándose la actuación del mismo actos propios de la Administración bajo cuyo servicio se encuentre. La responsabilidad se exigirá de conformidad con lo previsto en los artículos 139 y siguientes de esta Ley. Esta remisión al artículo 139 y siguientes supone la unificación del régimen sustantivo de la responsabilidad patrimonial de la Administración sin discriminar su actuación en régimen de Derecho público o privado.
} 
dad Social y sus servicios comunes (estatales o autonómicos), así como de las demás entidades y organismos del Sistema Nacional de Salud, por los daños y perjuicios causados con ocasión de la asistencia sanitaria ${ }^{27}$. Su tramitación se llevará a cabo de conformidad con los artículos 139 y siguientes de la Ley 30/1992.

\section{c) Normativa procesal}

El artículo 9.4 LOPJ en la redacción introducida por Ley Orgánica 6/1998, de 13 de julio, para adecuar su contenido a la Ley 29/1998, de 13 de julio, de la Jurisdicción Contencioso-Administrativa (en adelante LJCA), dispuso que conocerá este orden jurisdiccional de las pretensiones que se deduzcan en relación con la responsabilidad patrimonial de las Administraciones públicas y del personal a su servicio, cualquiera que sea la naturaleza de la actividad o el tipo de relación de que se derive. Si a la producción del daño hubieran concurrido sujetos privados (caso de los contratistas), el demandante deducirá también frente a ellos su pretensión ante este orden jurisdiccional ${ }^{28}$. Posteriormente, la Ley Orgánica 19/2003, de 23 de diciembre, ha añadido los siguientes párrafos: «Igualmente conocerán de las reclamaciones de responsabilidad cuando el interesado accione directamente contra la aseguradora de la Administración, junto a la Administración respectiva». «También será competente este orden jurisdiccional si las demandas de responsabilidad patrimonial se dirigen, ade-

\footnotetext{
${ }^{27}$ Algún sector doctrinal ha declarado que esta disposición adicional invade el campo reservado a la LOPJ por el artículo $122.1 \mathrm{CE}$, al remitir a la jurisdicción contencioso-administrativa las reclamaciones por daños frente a centros sanitarios concertados, cuando, por tratarse de sujetos privados, quedan sometidos, conforme al artículo 9.2 LOPJ, a la jurisdicción civil. Este precepto es una excepción al criterio subjetivo de delimitación jurisdiccional utilizado por el legislador en la reforma de la LOPJ al residenciar en la jurisdicción contencioso-administrativa el conocimiento de los litigios surgidos de los conciertos contratados por la Administración sanitaria con hospitales privados. Véase J.L. PIÑAR MAÑAS (dir.), La reforma del procedimiento administrativo. Comentarios a la Ley 4/1999, de 13 de enero, Dykinson, 1999, pp. 383 a 389. En referencia a las fundaciones de iniciativa pública, del mismo autor, «fundaciones constituidas por ente público. Algunas cuestiones», REDA, n. ${ }^{\circ}$ 97, pp. 37 a 63, así como J.L. Piñar Mañas y A. Real Pérez, Derecho de fundaciones $y$ voluntad del fundador, Marcial Pons, Madrid, 2000, p. 203.

${ }^{28}$ La reforma de la LOPJ era fundamental a fin de excluir de una vez por todas el conocimiento de las pretensiones sobre responsabilidad patrimonial de la Administración pública de otras jurisdicciones, y se hizo atendiendo a la doctrina del Tribunal Constitucional que había proclamado la necesidad de una Ley Orgánica para diseñar competencialmente los distintos órdenes jurisdiccionales y para definir su ámbito de conocimiento litigioso (STC 224/1993, de 1 de julio). En definitiva, el legislador optó por un criterio de delimitación jurisdiccional de corte estrictamente subjetivo, esto es, basado en la naturaleza pública del sujeto y no en la naturaleza de la relación jurídica o de la actividad generadora del daño. Aunque, extiende la competencia de la jurisdicción contencioso-administrativa en los supuestos de concurrencia de particulares en la producción del daño.
} 
más, contra las personas o entidades públicas o privadas indirectamente responsables de aquéllas».

Por su parte, el artículo 2.e) de la LJCA atribuye a esta jurisdicción el conocimiento de «la responsabilidad patrimonial de las Administraciones públicas, cualquiera que sea la naturaleza de la actividad o el tipo de relación de que derive, no pudiendo ser demandadas aquéllas por este motivo ante los órdenes jurisdiccionales civil o social». Añadiendo la disposición adicional decimocuarta de la Ley Orgánica 19/2003, de 23 de diciembre, un nuevo párrafo: «aun cuando en la producción del daño concurran con particulares o cuenten con un seguro de responsabilidad». Y en lógica, contrapartida se ha añadido también un nuevo apartado al artículo 21 de la LJCA para concretar que las aseguradoras de las Administraciones públicas se considerarán parte codemandada junto con la Administración a quien aseguren

El apartado d) del artículo 2 de la LJCA encomienda también a la jurisdicción contencioso-administrativa el conocimiento de los actos administrativos de control o fiscalización dictados por la Administración concedente, respecto de los dictados por los concesionarios de los servicios públicos que impliquen el ejercicio de potestades administrativas conferidas a los mismos, así como los actos de los propios concesionarios cuando puedan ser recurridos directamente ante este orden jurisdiccional de conformidad con la legislación sectorial correspondiente. Este precepto permite cierta administrativización de relaciones en principio privadas si la Administración interviene a instancias de los particulares fiscalizando la actuación de los concesionarios. La posibilidad de recurrir directamente los actos del concesionario queda supeditada a lo previsto en la legislación sectorial correspondiente.

\section{CUESTIONES QUE SUSCITAN EL RÉGIMEN APLICABLE DE RESPONSABILIDAD EXTRACONTRACTUAL DE LOS CONTRATISTAS}

Una primera cuestión podemos extraer de la normativa señalada: la pretendida unificación de régimen sustantivo, procedimental y jurisdiccional que el legislador ha previsto en esta materia ha quebrado en cuanto a la responsabilidad del contratista cuando produce un daño a terceros en la ejecución del contrato ${ }^{29}$. De una interpretación literal de los preceptos

\footnotetext{
29 R. BOCANEGRA SiERRA, en su día, llamó la atención acerca de que las previsiones legales en esta materia abrieron una situación de incertidumbre y confusión («Responsabilidad de contratistas y
} 
señalados comprobamos que el legislador utiliza expresiones como «autoridades y personal al servicio de las Administraciones públicas» para incluir su actuación dentro de la responsabilidad administrativa objetiva en las que no tienen cabida el contratista. El profesor GARCÍA DE ENTERRÍA ha venido señalando que cuando la Administración contrata un servicio público o una obra pública lo que desea es exteriorizar y externalizar dicha prestación, no pudiendo considerarse al contratista como integrado dentro de la organización administrativa ${ }^{30}$.

Y si bien es verdad que esta argumentación cuenta con toda la autoridad doctrinal para exigir, como debe ser, al contratista ${ }^{31}$ y no a la Administración la indemnización por los daños que éste haya podido irrogar durante la ejecución del contrato, no debemos olvidar que la actividad del contratista público es administrativa (servicio público) y de titularidad de una Administración pública. Desde un punto de vista de la dogmática jurídica, no cabe duda que la relación tercero-contratista es una relación jurídico privada, pero el substrato o fundamento de la que trae causa tampoco cabe duda que es público, se entabla a través de la gestión de una actividad administrativa de carácter público. Y a pesar de que la actual configuración del concesionario o contratista ha quedado reducida a un

concesionarios de la Administración pública por daños causados a terceros», REDA, n. ${ }^{\circ} 18,1978$, p. 308). También C. HoRgué BAENA en «La responsabilidad de contratistas por daños causados a terceros», $R A P$, n. ${ }^{\circ} 147,1998$, p. 339. Si aquella situación presentaba cierta complejidad cuando la normativa en vigor (LEF) era mucho más clara y precisa en muchos aspectos de su aplicación, en la actualidad, las dificultades han aumentado debido a la indeterminación normativa, jurisprudencial y doctrinal existente en esta materia.

${ }^{30}$ Son ilustrativas al respecto las palabras del profesor GARCíA DE ENTERRÍA: «¿Ha de entenderse que toda la responsabilidad civil en que pueda incurrir el concesionario de servicios públicos en ejercicio de la concesión se regirán en adelante por la nueva Ley y no por el Código Civil? No a nuestro juicio..., de la misma manera que los actos del concesionario no son actos administrativos, o sus contratos, contratos administrativos, o sus agentes, agentes administrativos, o sus fondos, en fin, fondos públicos, así su eventual responsabilidad no hay razón para que sea una responsabilidad administrativa. Únicamente cuando los daños se ocasionaran en el ejercicio de funciones públicas delegadas en el concesionario admitiría el régimen de responsabilidad administrativa» (Los principios de la nueva Ley de Expropiación Forzosa, Civitas, Madrid, 1984, pp. 197 a 203). De esta forma, GARCÍA DE ENTERRÍA delimita el ámbito de aplicación de la LEF y, por ende, la responsabilidad sujeta al régimen administrativo de los concesionarios de servicios públicos, en el sentido de afirmar que sólo se comprenden en dichos preceptos las hipótesis de que el concesionario ejercite verdaderos poderes públicos en nombre de la Administración concedente. Véanse también J.F. MESTRE DELGADO, «Las formas de prestación de los servicios públicos locales. Especial referencia a la concesión», en Tratado de Derecho Municipal, t. II, obra colectiva dirigida por S. MuÑOz MACHADO, Civitas, Madrid, 2003, p. 1489; y C. HORGUÉ BAENA, «La responsabilidad del contratista por daños a terceros», $R A P$, n. ${ }^{\circ} 147,1998$, p. 343.

${ }^{31}$ La Administración no podrá ni deberá convertirse en responsable universal de la gestión llevada a cabo por personas ajenas a su organización. Véase S. MuÑoz MACHADO, Responsabilidad civil concurrente de las Administraciones Públicas, Civitas, Madrid, 1992, pp. 162 y ss. 
modesto papel de intermediario o mero gestor del servicio, para hacer efectivos los derechos constitucionalmente reconocidos a los ciudadanos a través de las garantías que proporciona el procedimiento administrativo y la jurisdicción contencioso-administrativa, su responsabilidad no debería ser distinta a la de los agentes o mandatarios ocasionales de la Administración, pues actúa como su vicario y por su cuenta ${ }^{32}$, por lo que no debería sustanciarse, sin más, conforme a las reglas del Código Civil. La figura del contratista no es similar, ni mucho menos, a la del personal al servicio de la Administración, pero tampoco se trata de supuestos tan distintos que exijan tratamientos jurídicos tan diferenciados, sobre todo, si se trata de agentes o mandatarios ocasionales.

La pretensión del legislador de establecer el régimen jurídico del contratista (gestor indirecto de un servicio público o ejecutor de una obra pública) basado exclusivamente en un criterio subjetivo sin tener en cuenta la actividad que desarrolla puede producir en algunos casos disfunciones y falta de justicia material. Sujeto, actividad y fines son elementos estrechamente vinculados que no deberían ser aisladamente considerados por el legislador. De no entenderse así en la práctica puede producirse una diversidad de trato difícilmente justificable por el sólo dato de decidir gestionar indirectamente un servicio o ejecutar una obra pública por contrato ${ }^{33}$.

En otros muchos ámbitos o sectores en los que la Administración ha descentralizado funcionalmente o delegado en agentes o mandatarios pri-

\footnotetext{
${ }^{32}$ La STS de 24 de febrero de 2000, en el fundamento de derecho segundo, declara que cuando la gestión del servicio público tiene lugar de forma indirecta a través de las variadas fórmulas que nuestro ordenamiento jurídico permite, cabe percibir en todas ellas la presencia de la Administración y del prestador del servicio como colaboradores comprometidos en la consecución de un mismo fin, garantizar al ciudadano un servicio público eficaz. Anteriormente, la STS de 9 de mayo de 1989 (Ar. 4487) marcó, según la doctrina, un punto de inflexión en la jurisprudencia aunque sus argumentos no hayan sido ratificados en pronunciamientos posteriores, por cuanto fundamentaría la responsabilidad directa de la Administración en el dato de que toda la actuación del concesionario se imputa a ésta en tanto que delegado de la misma. Un comentario crítico a esta sentencia puede verse en M. Rebollo Puig, «Servicios públicos concedidos y responsabilidad de la Administración: imputación o responsabilidad por el hecho del otro», Revista Poder judicial n. ${ }^{\circ} 20,1990$ y en S. MuÑOZ MACHADO, La responsabilidad civil concurrente de las Administraciones públicas, Civitas, Madrid, 1992, pp. 129 y ss.

${ }^{33}$ Este es el fundamento que aparece fielmente reflejado por primera vez en el Dictamen del Consejo de Estado de 12 de julio de 1973, en el que se afirma: «que el derecho a ser indemnizado que asiste al particular lesionado por el funcionamiento de los servicios está configurado en términos sustantivos por el artículo 121 de la Ley de Expropiación Forzosa, con independencia de que la Administración mantenga la titularidad del servicio y lo gestione directamente o interponga un tercero, el concesionario. La utilización por la Administración de un servicio no puede trascender con efecto limitativo sobre los derechos y posición de los administrados lesionados por el servicio. Lo contrario produciría evidentes e inadmisibles consecuencias discriminatorias para supuestos objetivos idénticos».
} 
vados el ejercicio de determinadas actividades de carácter público, sometiéndolas a un régimen jurídico-privado, la doctrina y la jurisprudencia, incluso tratándose de agentes privados, aplican un concepto objetivo-funcional de poder público para someter su actuación a principios jurídicopúblicos $^{34}$. En este sentido debemos recordar que desde hace algunos años la jurisprudencia del TJUE viene elaborando una doctrina muy consolidada sobre el concepto funcional de Estado o de poder público con la intención de someter a las unidades descentralizadas funcionalmente de las Administraciones públicas a la normativa contractual pública europea ${ }^{35}$.

Como podemos comprobar es ésta una cuestión con muchas aristas y ramificaciones que nos obliga, en aras a una mayor claridad, a ir por par-

${ }^{34}$ En la materia concreta que nos ocupa, vid., E. RIVERo ISERN, El Derecho Administrativo y las relaciones entre particulares, cit.., p. 237; R. BOCANEGRA SIERRA, «La responsabilidad civil de los concesionarios...», cit.., p. 219; M. BELADIEZ RoJo, Responsabilidad e imputación de daños por el funcionamiento de los servicios públicos, cit.., p. 79; J. LEGUINA VILLA, La responsabilidad civil de la Administración pública, Tecnos, Madrid, 1997, p. 27; L. MARTín ReBOllo, «Responsabilidad patrimonial de la Administración Local» en Tratado de Derecho Municipal, obra colectiva dirigida por S. Muñoz Machado, Civitas, Madrid, 1998, p. 618; J. GonZÁlez Pérez, Responsabilidad patrimonial de las Administraciones Públicas, Civitas, Madrid, 1996, p. 180. No obstante, se han alzado algunas voces señalando que los argumentos esgrimidos corresponden más a la equidad y a la lógica del sistema que a una interpretación jurídica de los preceptos de la LEF; vid., M. ReBOLLO PuIG, «Servicios públicos concedidos y responsabilidad de la Administración», Revista del Poder Judicial n. ${ }^{\circ} 20,1990$, p. 29.

${ }^{35}$ Ejemplo de ello es la Sentencia del TJUE de 17 de diciembre de 1998, Asunto C-353/96 (Comisión contra Irlanda), en la que el Tribunal rastrea sobre la organización y funcionamiento del Servicio de Bosques irlandés, constituido en forma de sociedad mercantil sometido al Derecho privado, y concluye declarando a través de una interpretación funcional de Estado que este servicio depende en gran medida de los poderes públicos pues su composición y funcionamiento están previstos en la ley, por lo que debe entenderse incluido en el ámbito del Estado, aunque formalmente no sea parte de él. En iguales términos se pronunció el TJUE en las Sentencias de 15 de enero de 1998, Asunto C-44/96, Mannesmann; 10 de noviembre de 1998, Asunto C-360/96; 1 de febrero de 2001, Asunto C-237/99 y en la 10 de mayo de 2001, Asuntos acumulados C-223/99 y C-260/99, Ente Autónomo Fiera Internazionale de Milano; 15 de mayo de 2003, Asunto C-214/00, Comisión/España. Un comentario de todas ellas puede verse en F. VILLALBA PÉREZ, La contratación de las sociedades mercantiles en manos de las Administraciones Públicas: principios de publicidad y concurrencia. Fundamentos de su publificación, Tirant lo blanch, Valencia, 2003. Posteriormente, el TJUE ha condenado a España en Sentencias de 15 de mayo y de 16 de octubre de 2003, así como de 13 de enero de 2005 por no incluir correctamente en nuestra normativa interna el ámbito de aplicación subjetivo y objetivo fijado por las Directivas de contratación pública. Fruto de esas condenas ha sido la modificación del artículo 2.1 del TRLCAP introducida por el artículo 67 de la Ley 62/2003, de 30 de diciembre, de medidas fiscales, administrativas y del orden social que ha reformado el ámbito de aplicación subjetivo del TRLCAP (artículo 2 y la disposición adicional $6^{\mathrm{a}}$ ), sometiendo parcialmente al mismo (capacidad del contratista, publicidad del contrato, procedimientos de licitación y formas de adjudicación) a las sociedades mercantiles públicas que realicen actividades de interés general y cumplan con los requisitos establecidos en el artículos 2.1 del TRLCAP. Véase sobre este tema E. GARCíA DE ENTERRÍA, «El Tribunal de Justicia de las Comunidades Europeas constata y censura dos graves quiebras de nuestro Derecho Administrativo en materia de sujetos de Derecho público y de medidas cautelares contencioso-administrativa (Sentencia Comisión/España C-214/00, de 15 de mayo de 2003)», REDA, n. ${ }^{\circ} 119$ (2003). 
tes. Por ello, trataremos en primer lugar si la relación jurídica que entabla el tercero perjudicado con el contratista es estrictamente una relación jurídico-privada, y por tanto la responsabilidad será culposa, dolosa o cuando menos negligente de la señalada en el artículo 1902 del C.c; o por el contrario, se trata de una relación entremezclada de elementos privados (sujetos de la relación) y elementos jurídico-públicos (titularidad, poderes de dirección, inspección, vigilancia y control por parte de la Administración $)^{36}$ donde pudiéramos aplicar una responsabilidad administrativa u objetiva por daños (artículos 139 y siguientes de la Ley 30/1992). Cuestión prioritaria a determinar pues todas las demás cuestiones: normativa, procedimiento y jurisdicción competente, serán una concatenación lógica del régimen jurídico a aplicar. Veámoslo.

\section{ASPECTOS SUSTANTIVOS DE LA RESPONSABILIDAD PATRIMONIAL DEL CONTRATISTA}

Del régimen de responsabilidad extracontractual instaurado por el artículo 97 del TRLCAP: administrativo u objetivo basado en la antijuridicidad si el daño es imputable a la Administración, o, por el contrario, civil o subjetivo asentado en la culpa o negligencia del contratista, de entrada no podemos hacer una lectura clara y precisa dado que el precepto alude más a cuestiones adjetivas o procesales que a prejuzgar temas sustantivos o de fondo.

Sin embargo, el apartado $4^{\circ}$ del artículo 97 TRLCAP determina que la reclamación se formulará conforme al procedimiento establecido en la legislación aplicable en cada supuesto. De donde se desprende un sistema dual en materia de responsabilidad por daños casualizado en función del sujeto responsable. Si el daño es imputable a la Administración contratante, la responsabilidad será administrativa u objetiva por daños, la vía

\footnotetext{
36 Véase en este sentido E. RIVERo ISERN, que gráficamente calificó el supuesto como de relación jurídico-administrativa entre particulares (Derecho Administrativo y las relaciones entre particulares, cit., p. 239); R. BOCANEGRA SIERRA, «Responsabilidad de contratistas y concesionarios de las Administraciones públicas...», cit., pp. 404-405 y, posteriormente en la «responsabilidad civil de los concesionarios y contratistas de la Administración por daños causados a terceros», Documentación Administrativa n. ${ }^{\circ}$ 237-238, 1994, p. 219; L. MARTín ReBollo, «La responsabilidad de las Administraciones públicas», cit.., p. 89; S. MUÑOZ MACHADO, La responsabilidad civil concurrente de las Administraciones Públicas, cit., pp. 115-116; M. Rebollo PUIG, «Servicios públicos concedidos y responsabilidad de la Administración: imputación o responsabilidad por hecho de otro», cit., p. 28; J.L. IBAÑEZ GiL, La responsabilidad patrimonial de los poderes públicos, Actualidad Editorial, Madrid, 1994, p. 35; A. F. PANTAleón PRIETO, Responsabilidad civil: conflictos de jurisdicción, Madrid, 1985, p. 60.
} 
de reclamación es la establecida en el artículo 1.3 del RRP y su conocimiento queda residenciado en la jurisdicción contencioso-administrativa. Si es imputable al contratista habrá que instar dicha reclamación conforme a la legislación civil y ante los tribunales de este orden ${ }^{37}$.

Este cambio sustancial respecto del establecido en la LEF ha sido reconocido por el Consejo de Estado en el Dictamen 3425/2001 de 20 de diciembre, señalando que «la actual legislación de contratos administrativos tiene un alcance distinto y mucho más limitado que el previsto en la LEF para los supuestos de servicios públicos concedidos. El actual artículo 97 del TRLCAP determina la responsabilidad extracontractual directa del contratista por los daños que cause en la ejecución del contrato y admite la posibilidad de un requerimiento previo por parte del perjudicado a la Administración que deberá pronunciarse exclusivamente sobre la parte contratante a la que corresponda la responsabilidad. Una solución que evidencia una concepción por parte del legislador de contratos distinta a la señalada en la LEF de 1954 y en el RGCE de 1975».

Y este cambio se ha producido precisamente en una materia en la que su evolución parece ir en un sentido completamente distinto. El artículo 51 de la Ley 48/1998, de 30 de diciembre, de procedimientos de contratación en los sectores especiales de agua, energía, transporte y telecomunicaciones $^{38}$, que abre la gestión de estos servicios a empresas completamente privadas, permite a los usuarios de estos servicios interponer una previa reclamación ante la Administración que concedió el ejercicio y explotación del servicio y con la resolución administrativa, expresa o por silencio administrativo, acudir a la jurisdicción contencioso-administrativa. Esta misma Ley también atribuye a la Administración otorgante del servicio fijar las indemnizaciones que procedan previa reclamación de daños y perjuicios. Por otra parte, el artículo 67 de la Ley 62/2003, de 30

\footnotetext{
37 Aunque la referencia va dirigida a los concesionarios de servicios públicos bajo la vigencia del artículo 98 de la LCAP, vid., F. SOSA WAGNER, la gestión de los servicios públicos locales, $3^{\mathrm{a}}$ ed., Civitas, Madrid, 1997, p. 135. En relación al contratista en general véase también F. SOSA WAGNER y otros, Comentarios a la Ley de Contratos de las Administraciones Públicas, Cedecs, Barcelona, 1995, p. 85; A. Ballesteros Fernandez, Contratos de las Administraciones Públicas I, VV.AA., El Consultor, Madrid, 1995, p. 499; F. PANTAleón Prieto, Responsabilidad patrimonial..., cit., p. 410; E. Gamero CASADO, Responsabilidad administrativa: conflictos de jurisdicción, Aranzadi, Pamplona, 1997, p. 57.

${ }^{38}$ El artículo 51 de la Ley 48/1998 atribuye a los órganos de contratación de las Administraciones públicas respecto de las empresas públicas a ellas adscritas o vinculadas, y de las empresas privadas a las que hayan otorgado un derecho especial o exclusivo, las siguientes competencias: a) resolver las reclamaciones; b) acordar las medidas cautelares necesarias para asegurar la eficacia de la resolución que en su momento se dicte; c) fijar las indemnizaciones que procedan, previa la correspondiente reclamación de daños y perjuicios.
} 
de diciembre, de medidas fiscales, administrativas y del orden social, ha incorporado una disposición adicional decimosexta al TRLCAP ${ }^{39}$ que posibilita la interposición de recursos en los contratos de las sociedades mercantiles públicas, remitiendo su regulación a lo dispuesto en el artículo 51 de la Ley $48 / 1998$.

Como vemos, en este mismo sector, existe una clara tendencia por publificar determinados aspectos de las relaciones jurídico-privadas en aras a proteger y salvaguardar garantías ciudadanas. La Administración en el ejercicio de su potestad autoorganizatoria no podrá dejar sin contenido determinados preceptos constitucionales y legales que fueron redactados precisamente para cubrir los daños o perjuicios que su funcionamiento - normal o anormal- pudiera causar a los ciudadanos. La responsabilidad patrimonial de la Administración incluida en el texto constitucional (artículo 106.2) atiende directamente al derecho de los particulares a obtener una indemnización por toda lesión que sea consecuencia del funcionamiento de un servicio público, y no distingue si el servicio público es gestionado por un particular o por la propia Administración a la hora de fijar la cobertura del daño ${ }^{40}$. Por ello parece extremado deducir que una decisión organizatoria de la Administración, como es gestionar indirectamente el servicio o ejecutar por contrato una obra pública, pueda determinar una minoración de un derecho constitucionalmente reconocido y garantizado. El artículo 106.2 CE está redactado en clave del particular que sufre el daño como consecuencia del funcionamiento del servicio público y no del sujeto responsable. De lo que podríamos deducir que la voluntad el constituyente no era dejar

\footnotetext{
${ }^{39}$ Con la denominación de «recursos en materia de contratos de las sociedades sujetas a esta Ley», la disposición adicional decimosexta del TRLCAP -introducida por el artículo 67 de la Ley de acompañamiento a los PGE de 2004-, señala que a los efectos de reclamaciones y recursos en relación con los contratos a que se refiere el apartado $1^{\circ}$ del artículo 2 del TRLCAP se tendrá en cuenta lo dispuesto en el artículo 51 de la Ley 48/1998, de 30 de diciembre, sobre procedimientos de contratación en los sectores del agua, la energía, los transportes y las telecomunicaciones, por las que se incorporan al ordenamiento jurídico español las Directivas 93/38/CEE y 92/13/CEE. Véase hoy la Directiva 2004/17/CE, de 31 de marzo de 2004, sobre coordinación de los procedimientos de adjudicación de contratos en los sectores del agua, energía, transportes y servicios postales.

${ }^{40}$ La STS de 13 de febrero de 2003 (Sala 33 , Sección $6^{\text {a }}$ ) en la resolución de un conflicto de competencias ha declarado que el alcance general y unitario de la responsabilidad patrimonial de la Administración pública se desprende de los artículos 106.2 y 149.1.18 de la Constitución, por lo que es indiferente que la actividad administrativa haya tenido lugar en el estricto ejercicio de una potestad administrativa o en forma de una mera actividad material o en omisión de una obligación legal, del mismo modo que es también indiferente la naturaleza, pública o privada, de la relación de que derive. Destacando también que el procedimiento unitario es previo y obligado al planteamiento jurisdiccional de toda reclamación de esta naturaleza, hasta el punto de que ha desaparecido la posibilidad de la acción jurisdiccional autónoma de resarcimiento que la normativa derogada preveía (artículo 40 LRJAE).
} 
fuera de la responsabilidad patrimonial pública los servicios públicos gestionados de forma indirecta ${ }^{41}$.

Se podría mantener que el régimen objetivo de responsabilidad establecido constitucionalmente es el propio de la Administración pública como sostener que deriva del servicio público con independencia de quien lo esté gestionando. En definitiva, defender tanto una noción subjetivaorgánica como material-funcional de la noción de servicio público a efectos de la responsabilidad.

Esta es la razón por la que parte de la doctrina propugna que deba mantenerse el régimen sustantivo de responsabilidad pública ante terceros por daños en la ejecución de los contratos administrativos y, sobre todo, en la gestión de los servicios públicos, ya sea la responsabilidad imputable a la Administración como si lo es al contratista ${ }^{42}$. Tesis que resulta convincente por su indudable apoyo constitucional pero de difícil encaje legal pues la dualidad jurisdiccional dispuesta en el artículo 97 del TRLCAP (contencioso-administrativa si es imputable a la Administración; civil si lo es al contratista) impedirá que tenga visos de futuro ${ }^{43}$.

${ }^{41}$ El Consejo de Estado ha declarado en los Dictámenes 3225/2002 de 16 de enero de 2003, y $3433 / 2001$ de 21 de febrero de 2002, que en ningún caso puede entenderse que el artículo 97.3 del TRLCAP tiene la virtualidad de privar a los particulares de una garantía constitucional (artículo 106.2 CE) como es la de exigir directamente a la Administración titular de la obra o del servicio la responsabilidad patrimonial correspondiente, aunque haya un contratista interpuesto. Véanse también los dictámenes 3991/1998 y 4049/1998, de 26 de noviembre; 4076/1998 de 10 de diciembre; $669 / 1999$ de 22 de abril; 3509/2000 de 23 de noviembre; 3622/2000 de 21 de diciembre y $3425 / 2001$ de 21 de diciembre.

${ }^{42}$ Entre otros, vid., J. SUAY RINCÓN, «Ejecución del contrato administrativo. La cesión del contrato y la subcontratación», en Comentarios a la Ley de Contratos de las Administraciones Públicas, Civitas, Madrid, 1996, p. 415; J. CoRella Pla, Contratación pública, II, VV.AA., Marcial Pons, Madrid, 1997, p. 182; M. Beladiez RoJo, Responsabilidad e imputación por daños..., cit., p. 264.

43 Desde estas posturas doctrinales la responsabilidad del concesionario o del contratista por daños deriva directamente de la antijuridicidad del resultado lesivo y no de la culpabilidad o ilicitud de la conducta. Las Sentencias del Tribunal Supremo de 25 de enero de 1992 (Ar. 1343) y 19 de mayo de 1987 (3615) declaran que ante el tercero dañado, la cobertura de la lesión que da derecho a una indemnización reparatoria es la misma la haya producido la Administración a través de agentes insertos en su organización o un sujeto privado que colabora en la gestión de una actividad de titularidad pública. Véase C. Horgué BAENA, «La responsabilidad del contratista por daños causados a terceros en la ejecución de los contratos administrativos», $R A P$, n. ${ }^{\circ} 147,1998$, pp. 343 y 344 . La Sentencia de 25 de febrero de 1998 (Sala 33a, Ponente González Rivas), ante la reclamación de indemnización por los usuarios de un servicio público de los daños producidos en la ejecución del contrato, declara que, «aunque la reclamación efectuada por los perjudicados no fue objeto de resolución expresa por parte de la Administración, ello no excluye el carácter estrictamente administrativo de la cuestión planteada que afecta a la organización de un servicio público, cuyo directo control sigue correspondiendo a quien ostenta la titularidad del servicio...» «La relación entablada entre el usuario y el contratista no es una relación estrictamente contractual pues afecta a la prestación de 
El régimen sustantivo está íntimamente unido, al menos desde una vertiente práctica, al régimen procesal y si tales reclamaciones se sustancian ante los tribunales civiles, éstos aplicarán los principios y criterios propios del sistema de culpa en la imputación, deslindando así el régimen de responsabilidad extracontractual de los contratistas del que se establece para la Administración ${ }^{44}$, por lo que el contratista responderá conforme al sistema de responsabilidad civil por culpa según la doctrina elaborada por los tribunales civiles ${ }^{45}$.

Una excepción al reiterado conocimiento de los tribunales civiles en esta materia lo constituye la Sentencia del Tribunal Supremo $\left(\right.$ Sala $\left.1^{\text {a }}\right)$ de 20 de febrero de 2003, que atribuye a la jurisdicción contencioso-administrativa el conocimiento de la responsabilidad patrimonial de un contratista. El tribunal civil declara que «una consolidada doctrina jurisprudencial viene desdibujando la antigua concepción del predominio de la jurisdicción civil para el conocimiento de los contratos entre entidades públicas y privadas. Esta concepción debe quedar superada y ser reemplazada por la teoría de la denominada modulación del contrato por parte de la Administración, que atiende de modo decisivo a la finalidad pública o privada del convenio en cuestión... Los contratos, no obstante su factura civilística, deberán ser calificados de administrativos y su conocimiento atribuido a la jurisdicción de ese orden cuando tengan por objeto inmediato la gestión de una obra o servicio público, entendido éste en su acepción más amplia comprensiva de cualquier actividad desarrollada por la

\footnotetext{
un servicio público». Véanse también las SSTS de 4 de julio y 2 de diciembre de 2002 y 31 de enero y 20 de febrero de 2003.

${ }^{44}$ Este deslinde está alterando el entendimiento que hasta ahora se había alcanzado por la doctrina científica, el Consejo de Estado y los Tribunales contencioso-administrativos. Véase al respecto F. Sosa Wagner, La gestión de los servicios públicos locales, Civitas, Madrid, 2000, p. 135; del mismo autor y VV.AA, La Ley de Contratos de las Administraciones Públicas, Cedecs, Barcelona 1995, p. 85; A. Ballesteros Fernández, Contratos de las Administraciones Públicas, El Consultor, Madrid, p. 499, I, VVAA; Manual de Gestión de Servicios Públicos y Locales, El Consultor, Madrid, 2005, pp. 183-184 y 313. F. CASTILlO BLANCO, «Consideraciones generales en torno a la ejecución del contrato administrativo en la reciente Ley de Contratos de las Administraciones Públicas», en Estudios sobre la contratación en las Administraciones Públicas, Comares, Granada, 1996, pp. 292 y ss; F. PANTALeÓn Prieto, Responsabilidad patrimonial..., cit., p. 410; E. GAMERo CASADO, Responsabilidad administrativa: Conflictos de jurisdicción..., cit., p. 57.

${ }^{45}$ En el conocimiento de este tipo de litigios, los tribunales civiles han tenido la ocasión de desarrollar una doctrina jurisprudencial caracterizada por: $1^{\circ}$ ) por aplicar el criterio de culpa, aunque en ocasiones se haya introducido una cierta objetivación; $2^{\circ}$ ) por considerar que el carácter de servicio público de la actividad y la titularidad del mismo que corresponde siempre a la Administración, incluso cuando no lo gestiona directamente, determina que ésta sea responsable de su funcionamiento siempre que los daños que se produzcan sean consecuencia de una «culpa in vigilando»; $3^{\circ}$ ) que la responsabilidad entre el concesionario y el contratista y la Administración, cuando ésta última haya contribuido a la producción del daño, es solidaria.
} 
Administración como necesaria para la satisfacción del interés general atribuido a la esfera de su competencia» ${ }^{46}$.

También son ilustrativos al respecto los argumentos esgrimidos por el Consejo Consultivo de Andalucía en el Dictamen 60/2000 sobre la responsabilidad de la Empresa Pública de Emergencias Sanitarias de Andalucía, en el que declara que: «...La Constitución ha erigido la noción objetiva de servicio público en la clave de bóveda del sistema de responsabilidad patrimonial, que no puede quedar al albur del concreto ejercicio de la potestad autoorganizatoria de cada una de las Administraciones Públicas. La sujeción, en términos generales, de la actuación del ente que presta el servicio a criterios empresariales y a esquemas iusprivatistas en aspectos organizativos y de gestión no releva de la aplicación del régimen de responsabilidad patrimonial previsto en el artículo 106.2 de la Constitución. Antes al contrario, dicho régimen es un límite infranqueable que no puede ser esquivado por la libertad de autoorganización y uso de las formas jurídicas admitidas en Derecho, so pretexto de la mayor eficacia y agilidad de las nuevas formas de gestión de los servicios públicos...En definitiva, independientemente del dato de la personificación, lo relevante es que la responsabilidad invocada por el reclamante trae causa del funcionamiento de un servicio público regulado por normas de Derecho Administrativo».

En el mismo sentido se ha pronunciado la STS de 13 de febrero de 2003 declarando que «la unidad procedimental, jurisdiccional y de régimen jurídico es consecuencia lógica del sistema único, directo y objetivo de responsabilidad patrimonial de la Administración que tiene su fundamento en el funcionamiento de los servicios públicos, cláusula que engloba cualquier tipo de actuación de aquélla».

Estas interpretaciones se desprenden de la amplitud de la cláusula general utilizada por el legislador: funcionamiento normal o anormal de los servicios públicos. También de la dificultad existente en el régimen jurídico-privado de responsabilidad para probar por el tercero dañado la culpa o el dolo del agente productor del daño, por mucho que la jurisdicción civil y laboral hayan ampliado la tendencia objetivadora al ámbito de las relaciones jurídico-privadas ${ }^{47}$.

\footnotetext{
46 Pueden verse también las SSTS (Sala $3^{\mathrm{a}}$ ) de 8 de mayo y 7 de julio de 2001 extraídas de la página www.tirantonline.com.

${ }^{47}$ F. PANTALEón reconoce que la doctrina civilista objetiviza cada vez más el resultado dañoso y señala que del análisis de la jurisprudencia civil recaída en materia de responsabilidad de contratistas de la Administración no puede afirmarse que en esta sede jurisdiccional los particulares se hayan
} 


\section{PROCEDIMIENTO PARA RECLAMAR LA RESPONSABILIDAD DEL CONCESIONARIO O CONTRATISTA}

El procedimiento para reclamar la indemnización también ha cambiado en la regulación actual. La LEF de 1954 disponía que la reclamación debía dirigirse (de forma imperativa) a la Administración otorgante de la concesión que venía obligada a pronunciarse sobre la procedencia de la indemnización, la cuantía de la misma y quien debía pagarla. Esta resolución dejaba abierta la vía contencioso-administrativa. Los Reglamentos de Expropiación de 1957 y de Contratos del Estado de 1975 detallaban los trámites a seguir. El régimen legal se caracterizaba por un único procedimiento administrativo y una única jurisdicción competente, la contencioso-administrativa ${ }^{48}$.

Posteriormente, la Ley 30/1992 reguló de nuevo el régimen de responsabilidad patrimonial de la Administración sin hacer referencia alguna al procedimiento a seguir cuando la responsabilidad se imputase al contratista, pero, al no derogar expresamente el artículo 123 de la LEF, cabía pensar que su contenido siguió vigente hasta la aprobación de la LCAP de 1995. Antes de esa fecha, el RRP de 1993 reguló los procedimientos en los que la responsabilidad se imputase a la Administración contratante, sin especificar nada en los casos en los que la responsabilidad fuese imputada al contratista. Esta indeterminación posiblemente obedeciera a que el RRP carecía de habilitación legal para un desarrollo más específico. Ahora bien, si mantenemos que en esa época seguía vigente la regulación contenida en el artículo 123 de la LEF, la validez del Reglamento es cuando menos dudosa por no respetar el principio de jerarquía normativa.

El artículo 98 de la LCAP de 1995 estableció una nueva regulación implantando una dualidad procedimental y jurisdiccional para exigir la

\footnotetext{
visto menos protegidos en sus reclamaciones indemnizatorias que si hubiesen sido instadas ante los tribunales contencioso-administrativos (Responsabilidad patrimonial de las Administraciones públicas...cit., p. 412).

${ }^{48}$ Bajo la vigencia de la LEF el requerimiento previo a la Administración contratante tenía carácter preceptivo para el tercero dañado. La Administración debía pronunciarse, también con carácter preceptivo, sobre la procedencia de la indemnización, la parte responsable e, incluso, la cuantía de la misma; un pronunciamiento que revestía los caracteres propios de las resoluciones administrativas residenciables, por tanto, en la jurisdicción contencioso-administrativa. Según la doctrina, su naturaleza sería la de una competencia arbitral en resolución de un conflicto entre particulares, cualificada por el dato de que la Administración tiene igualmente que decidir en dicha reclamación si concurre alguna causa que desvíe hacia ella la responsabilidad. Véase el comentario que realiza L. MARTín ReBOllo al artículo 97 del TRLCAP en Leyes Administrativas, Aranzadi. $9^{\mathrm{a}}$ ed., 2003, pp. 642 y 643 .
} 
responsabilidad extracontractual al contratista en función del sujeto responsable -Administración o contratista-. Su contenido, como hemos visto, pasó posteriormente al TRLCAP de 2000 (artículo 97) con un pequeño matiz al eliminar el término civil para referirse a la acción. La utilización por parte del legislador de una ley de contenido contractual en lugar de la más específica de responsabilidad patrimonial para regular una responsabilidad de naturaleza extracontractual sorprendió a algún sector doctrinal, puesto que la responsabilidad del contratista nace fuera del contrato aunque se produzca como consecuencia de la ejecución de éste.

El artículo 97 del TRLCAP al igual que su predecesor (artículo 98 de la LCAP) descansa sobre la cualidad del sujeto responsable al disponer que los terceros dañados podrán (potestativamente) requerir dentro del año siguiente a la producción del hecho, al órgano de contratación para que éste, oído el contratista, se pronuncie sobre a cual de las partes contratantes corresponde la responsabilidad de los daños. Y en función de esa decisión, el damnificado podrá dirigirse a la Administración mediante la apertura del correspondiente procedimiento administrativo de responsabilidad patrimonial, o bien al contratista a través de la vía civil ordinaria conforme al artículo 1902 y siguientes del C.c ${ }^{49}$. El apartado $4^{\circ}$ del artículo 97 TRLCAP es claro al especificar que «la reclamación se formulará conforme al procedimiento establecido en la legislación aplicable a cada caso» ${ }^{50}$. Como vemos se produce un giro radical respecto al tratamiento anterior al comportar un previo pronunciamiento administrativo y un posterior judicial que será civil si el responsable es el contratista o contencioso-administrativo si la responsable es la Administración. Se ha separado el procedimiento según se exija a la Administración o al contratista y, sobre todo, se ha detraído de la esfera de la Administración la atribución de determinar la responsabilidad del contratista frente al tercero. Lo único que se prevé ahora es un requerimiento previo y opcional a la Administración contratante para que se pronuncie sobre quién es el responsable.

\footnotetext{
${ }^{49} \mathrm{Al}$ no ser el contratista una persona encuadrada en la organización de la Administración pública sino una persona privada.

${ }^{50}$ Frente al carácter preceptivo de la intervención de la Administración a la hora de determinar la procedencia de la indemnización establecida en los artículos 123 LEF y 134 RGCE, ahora el artículo 97 del TRLCAP, prevé como única intervención administrativa el pronunciamiento de la Administración contratante a un requerimiento facultativo sin que se derive obligación alguna de instarlo para el tercero. El pronunciamiento del órgano de contratación, en caso de ser solicitado, se reduce ahora a la decisión de a cuál de las partes contratantes le corresponde la responsabilidad por daños, decisión que enlazará con el ejercicio de la acción que deba interponerse en cada caso. SÁNCHEZ MoRÓN entiende que la decisión que adopte la Administración es recurrible en vía contencioso-administrativa tanto por el perjudicado como por el contratista (Derecho Administrativo. Parte General, Tecnos, Madrid, 2005, p. 905).
} 
Ahora bien, este requerimiento previo del tercero dañado al órgano de contratación para conocer el sujeto responsable ${ }^{51}$ y el posterior desglose jurisdiccional puede complicarse por distintas causas. Veamos algunas:

- La resolución administrativa decidiendo quién es el responsable y abriendo la vía procesal oportuna ¿podrá ser impugnada por el contratista y el reclamante? ¿A través de qué vía? ${ }^{52}$ ¿Es un acto administrativo el que abre la vía civil de reclamación? ¿Tendrá carácter resolutorio o, por el contrario, de acto trámite ${ }^{53}$ ?

Podrá argumentarse que la decisión de la Administración contratante resolviendo el requerimiento previo puede ser fiscalizable por los tribunales contencioso-administrativos siempre que cumpla los requisitos propios de justiciabilidad de los actos administrativos. Pero, ¿sobre qué extremos se pronunciarán los tribunales contencioso-administrativos si el objeto del proceso ha quedado únicamente circunscrito a quién es responsable? No cabe duda que la decisión de los tribunales podrá abarcar todos los extremos en relación a la Administración pública pero no las cuestiones que afecten al contratista, además la resolución de la Administración declarando la responsabilidad de los sujetos intervinientes no es vinculante ni para el contratista ni para los tribunales a la hora de decidir. Y si tal decisión no es vinculante y lo único que permite es al ejercicio de una acción civil, es porque no tiene verdadera naturaleza de resolución administrativa.

- El procedimiento establecido en el artículo 97 del TRLCAP ¿será aplicado también a los contratos privados que celebren las Administraciones públicas?

\footnotetext{
${ }^{51}$ Si bien el trámite previo del artículo 97.3 TRLCAP tiene el propósito de aliviar la carga del tercero lesionado para poder conocer el origen exacto del daño, no logra la finalidad perseguida, puesto que la Administración puede apreciar erróneamente la determinación de la responsabilidad y ser corregida en vía jurisdiccional. Circunstancia que retrasaría enormemente la efectividad de la reparación, sin olvidar además que la Administración también puede tener dudas sobre quién debe asumir la responsabilidad en el caso concreto -contratista o ella misma- y esa indeterminación provoque una falta de pronunciamiento expreso, lo que introduciría un importante factor de inseguridad en perjuicio del interesado.

${ }^{52} \mathrm{Si}$ el requerimiento a la Administración para que se pronuncie sobre a quién se imputa el daño es opcional -el particular puede decidir incluso no solicitarlo y dirigirse directamente a los tribunales-, la determinación de responsabilidad de los contratistas por daños a terceros ha dejado de ser competencia de la Administración contratante.

${ }^{53}$ Sobre la posible recurribilidad de los actos trámite, véase la STJUE de 15 de mayo de 2003, Asunto C-214/00 (Comisión/España) que recomienda a los tribunales contencioso-administrativos españoles una interpretación amplia de la admisibilidad de los actos trámite, sobre todo si producen indefensión o «perjuicios irreparables a derechos o intereses legítimos». vid. El comentario sobre la misma del profesor E. GARCÍA DE ENTERRÍA en REDA, n. ${ }^{\circ} 119$, septiembre 2003, pp. 471-487.
} 
La contestación creo que debe ser afirmativa pues la determinación de la responsabilidad no depende de la naturaleza del contrato, no deriva de éste al tener carácter extracontractual aunque se origine como consecuencia de la ejecución del contrato. Podría pensarse que el requerimiento previo a la Administración es cuando menos innecesario en los contratos privados en los que la demanda deberá residenciarse directamente en la jurisdicción civil, pero, realmente no lo es, porque al no tratarse de una acción contractual si la Administración no decide previamente quién es el responsable, el reclamante no sabrá contra quien dirigirse, de cuyo conocimiento dependerá también la vía procesal adecuada.

- ¿Por qué ha de interponerse una previa reclamación del tercero dañado al órgano de la contratación si se trata de una responsabilidad de carácter extracontractual aunque se origine como consecuencia de la ejecución de un contrato?

- Si la resolución administrativa previa decide que el responsable es el contratista y esta resolución es impugnada en vía contenciosoadministrativa por éste y a la vez por el reclamante en la vía civil ¿no podría terminar en sendas sentencias contradictorias?

Por todo ello creemos que sería más adecuado y eficaz que el tercero dañado se dirigiera directamente a la Administración titular del servicio a través del procedimiento administrativo de solicitud de responsabilidad patrimonial establecido en los artículos 139 y siguientes de la Ley 30/1992, y posteriormente la Administración ejerciera la acción de regreso sobre el patrimonio del contratista.

Así lo ha reconocido el Consejo de Estado en el Dictamen de 16 de enero de 2003, al señalar que «no cabe entender que el artículo 97.3 TRLCAP tiene la virtualidad de privar a los particulares de una garantía constitucional (artículo 106.2 CE) como es la de exigir directamente a la Administración titular de la obra o del servicio causante del daño la responsabilidad correspondiente, aunque haya un contratista interpuesto». «Desde que se implantó en el ordenamiento jurídico español el sistema de responsabilidad objetiva de la Administración pública (artículo 121 LEF), las leyes respectivas han venido declarando que los particulares tendrán derecho a ser indemnizados por la Administración correspondiente en toda lesión que sufran en cualquiera de sus bienes o derechos, salvo en los casos de fuerza mayor, siempre que la lesión sea consecuencia del funcionamiento normal o anormal de los servicios públicos. Y este título de imputación, basado exclusivamente en la relación de causalidad, no se descarta por el hecho de que exista un contratista interpuesto para la eje- 
cución de la obra o para la prestación del servicio, por lo que, en tales casos, si se acuerda indemnizar a la parte reclamante, su abono deberá realizarlo la propia Administración, sin perjuicio de que la misma ejerza, en su caso, la acción de regreso frente a la empresa contratista» ${ }^{54}$.

El fundamento de esta alternativa procedimental radica en que, de acuerdo con el principio general de responsabilidad objetiva de la Administración proclamado en el artículo 106.2 CE, lo verdaderamente importante es que el daño se ha causado como consecuencia de la ejecución de una obra pública promovida por la Administración o por el funcionamiento de un servicio público cuya titularidad pertenece también a la Administración. Por tanto, como quiera que la titularidad de la actividad que origina el perjuicio antijurídico corresponde a la Administración como dueña y señora del servicio, en principio, quien debe responder es la propia Administración, sin perjuicio de que con posterioridad -en el supuesto que se considere que la culpa es del contratista- pueda repercutir sobre éste la indemnización mediante la correspondiente acción de regreso. Y para tal repercusión tendrá plenos efectos la relación contractual entre las partes. Esta opción parece la más razonable habida cuenta de que la titular de la actividad, la Administración, en ningún momento deja de ejercer sus potestades, por lo que debería también asumir la responsabilidad de los daños que su ejecución pueda causar a terceras personas. La STS de 25 de febrero de 1998 señala que «la posición del sujeto dañado no tiene por qué ser recortada en su esfera garantizadora frente a aquellas actuaciones de titularidad administrativa en función de cuál sea la forma en que son llevadas a cabo y sin perjuicio, naturalmente, que el contratista y el concesionario puedan resultar también sujetos imputables».

Por consiguiente, consideramos más expeditivo y eficaz para el tercero lesionado no entrar en discusión sobre si el daño es imputable a la Administración o al contratista y remitirse a las reglas unitarias del régimen de responsabilidad administrativa por daños que proporciona a los damnificados un mayor margen de seguridad.

\section{JURISDICCIÓN COMPETENTE PARA CONOCER LA RESPONSABILIDAD DEL CONTRATISTA}

Hasta hace poco tiempo ha existido cierta complejidad normativa y bastante disparidad de criterios doctrinales y jurisprudenciales a la hora de

\footnotetext{
${ }^{54}$ Véanse también los Dictámenes del Consejo de Estado de 21 de febrero y 21 de marzo de 2002. La STS de 28 de junio de 2004 (Sala $3^{\text {a }}$, R-5619/2000) decreta la responsabilidad concurrente y solidaria de un Consorcio, de la Autoridad Portuaria y de un Ayuntamiento, y la consiguiente condena a indemnizar a la recurrente por los daños causados como consecuencia de la ejecución de una obra pública.
} 
abordar la jurisdicción competente para conocer los conflictos en materia de responsabilidad patrimonial de las Administraciones públicas. Este ha sido uno de los problemas más engorroso al que se ha enfrentado nuestro sistema de responsabilidad patrimonial, por la posibilidad de deducir la reclamación ante los cuatro órdenes jurisdiccionales ${ }^{55}$, en función de la concurrencia de determinadas circunstancias, lo que suponía una ausencia de uniformidad sustantiva y la inexistencia de un verdadero sistema de responsabilidad de todas las Administraciones públicas exigido por el artículo 149.1.18 CE. Los intentos de corregir este estado de cosas pasaban por las oportunas modificaciones legales que procediesen a la unificación del régimen sustantivo y jurisdiccional cuyo primer intento - un tanto desafortunado- se concretó en la Ley 30/1992 ${ }^{56}$ que no logró disipar por completo las dudas, ni alteró la práctica de los operadores jurídicos.

Posteriormente, el artículo 98 de la LCAP de 1995 y el vigente 97 del TRLCAP, no abordaron expresamente el tema de la jurisdicción competente para conocer de las reclamaciones de responsabilidad con ocasión de la ejecución de los contratos administrativos, a diferencia de la LEF que inequívocamente aludía a la jurisdicción contencioso-administrativa. El apartado $4^{\circ}$ del artículo 97 del TRLCAP, incidentalmente alude a que la

55 Véanse F. PANTALEÓN, «Responsabilidad patrimonial de las Administraciones públicas: sobre la jurisdicción competente», REDA, n. ${ }^{\circ}$ 91, 1996, pp. 403 a 413; A. PALMA DEL TESO, «El lamentable peregrinaje jurisdiccional entre el orden social y el contencioso-administrativo en materia de reclamaciones de indemnización por daños derivados de la deficiente atención sanitaria de la seguridad social», REDA, $\mathrm{n}^{\circ}$ 89, 1996, pp. 135 a 148; L. GARCÍA DEL RIO, «La problemática del artículo 9.4 párrafo segundo de la Ley Orgánica del Poder Judicial en los supuestos de participación de sujetos públicos y privados en la provocación del daño», Al Día Información Jurídica n. ${ }^{\circ}$ 25, 2002, pp. 1 a 4; M.A. ORRIOLs SALLES, «Un paso atrás en el principio de unidad jurisdiccional en materia de responsabilidad de la Administración como consecuencia de la presencia de compañías aseguradoras en el proceso», Diario la Ley n. ${ }^{\circ} 5720$ de 17 de febrero de 2003, pp. 1 a 4. E. GAMERO CASADO, Responsabilidad administrativa: conflicto de jurisdicción, Pamplona, 1997: A. HuERGO LORA, «El seguro de responsabilidad civil de las Administraciones Públicas y la doctrina de la "vis atractiva"», REDA 122, 2004, pp. 199-222; F.J. DE AHUMADA Ramos, Responsabilidad Patrimonial de las Administraciones Públicas. Elementos estructurales: lesión de derechos y nexo causal entre la lesión y el funcionamiento de los servicios, Aranzadi, Pamplona, 2004.

${ }^{56}$ En efecto, el artículo 144 de la Ley 30/1992 estipulaba que cuando las Administraciones Públicas actúen en relaciones de Derecho privado, responderán directamente de los daños y perjuicios causados por el personal que se encuentre a su servicio, considerándose la actuación del mismo actos propios de la Administración bajo cuyo servicio se encuentren. Por su parte, el artículo 145 estableció que los particulares exigirán directamente a la Administración pública correspondiente las indemnizaciones por los daños y perjuicios causadas por las autoridades y personal a su servicio. Se instituía así la exigencia de reclamación directa a la Administración, sin embargo, simultáneamente, y de manera poco afortunada, el artículo 146 aludía a la posibilidad de exigir la responsabilidad civil al personal al servicio de la Administración, de acuerdo con lo previsto en la legislación correspondiente, previsión suprimida definitivamente por la Ley 4/1999. Finalmente, el artículo 142.6 que consagró el primer intento de unificación jurisdiccional señalaba que la resolución administrativa de los procedimientos de responsabilidad patrimonial, cualquiera que fuese el tipo de relación pública o privada, pone fin a la vía administrativa. 
reclamación se formulará, en todo caso, conforme al procedimiento establecido en la legislación aplicable en cada supuesto.

Las dudas sobre la unificación jurisdiccional no quedaron despejadas hasta los años 1998-1999 con la aprobación de la LJCA, las modificaciones de la LOPJ y de la propia Ley 30/1992, que de manera definitiva consagraron la unificación del régimen sustantivo (sistema de responsabilidad objetiva) y de régimen jurisdiccional, concretando que la reclamación por responsabilidad de la Administración se ventilará necesariamente y en todo caso ante la jurisdicción contencioso-administrativa, después de un previo pronunciamiento de ésta. De las previsiones contenidas en la LOPJ; LJCA y Ley 30/1992, podemos deducir una clara voluntad del legislador de residenciar en la jurisdicción contencioso-administrativa todas las reclamaciones por responsabilidad dirigidas contra la Administración, sea cual sea la naturaleza de la actividad o relación entablada (pública o privada). Dejando a salvo, claro está, la responsabilidad penal en caso de delitos cometidos por las autoridades y personal a su servicios que conocerá la jurisdicción penal.

El apartado segundo del artículo 9.4 LOPJ en la redacción dada por Ley Orgánica 6/1998, de 13 de juli ${ }^{57}$, dispone que conocerá la jurisdicción contencioso-administrativa de «las pretensiones que se deduzcan en relación con la responsabilidad patrimonial de las Administraciones públicas y del personal a su servicio, cualquiera que sea la naturaleza de la actividad o el tipo de relación de que se derive. Si a la producción del daño hubieran concurrido sujetos privados (caso del contratista), el demandante deducirá también frente a ellos su pretensión ante este orden jurisdiccional». De este último párrafo se puede deducir, a sensu contrario, que el legislador admite la competencia del orden civil en caso de no concurrencia del contratista con la Administración en la producción del daño. Posteriormente, la Ley Orgánica 19/2003, de 23 de diciembre, ha introducido un nuevo párrafo señalando que también será competente el orden jurisdiccional contencioso-administrativo si las demandas de responsabilidad patrimonial se dirigen, además, contra las personas o entidades públicas o privadas indirectamente responsables de la Administración, con lo que vuelve a reiterar la necesidad de una concurrencia de causas.

Como vemos, también en el aspecto jurisdiccional ha optado el legislador en la reforma por un criterio estrictamente subjetivo basado en la natu-

\footnotetext{
57 Modificación producida para adaptar su contenido al de la Ley 29/1998, de 13 de julio, de la Jurisdicción Contencioso-Administrativa, atendiendo a la doctrina constitucional sobre la necesidad de una ley orgánica para delimitar los distintos órdenes jurisdiccionales. La reforma de la LOPJ era fundamental para excluir, de una vez por todas, las pretensiones de responsabilidad patrimonial de la Administración pública ante otras jurisdicciones. J.A. SANTAMARÍA PASTOR, Principios de Derecho Administrativo General. II. Iustel. Madrid. 2004, p. 517.
} 
raleza pública del sujeto y no en la naturaleza de la actividad generadora del daño o de la relación jurídica ${ }^{58}$.

Por su parte, el artículo 2 e) de la LJCA dispone también que este orden jurisdiccional conocerá de las cuestiones que se susciten en relación con la «responsabilidad patrimonial de las Administraciones Públicas, cualquiera que sea la naturaleza de la actividad o el tipo de relación de que derive, no pudiendo ser demandadas aquellas por este motivo ante los órdenes jurisdiccionales civil o social». En el concepto de «responsabilidad patrimonial de las Administraciones públicas» se incluye la de sus autoridades y la del personal a su servicio, no la del contratista, que queda fuera de su ámbito. Por otra parte, el apartado d) de este mismo precepto dispone que la jurisdicción contencioso-administrativa conocerá de los actos del concesionario cuando puedan ser recurridos directamente ante este orden jurisdiccional de conformidad con la legislación sectorial correspondiente. Remisión que queda supeditada a lo previsto en la «legislación sectorial correspondiente» y que, hoy por hoy, impedirá, en muchos casos, el mencionado conocimiento. La Ley Orgánica 19/2003, de 23 de diciembre, ha añadido un nuevo párrafo al artículo 2 e) de la LJCA señalando que será también competente la jurisdicción contencioso-administrativa para conocer la responsabilidad patrimonial de las Administraciones públicas «aun cuando en la producción del daño concurran con particulares o cuenten con un seguro de responsabilidad».

Finalmente, la Ley 4/1999, de 13 de enero, no sólo aclaró la unificación del régimen sustantivo sino que volvió a ratificar lo previsto en la LOPJ y en la LJCA sobre la unidad jurisdiccional, añadiendo en la disposición adicional $12^{\mathrm{a}}$ que la responsabilidad de las entidades, servicios y organismos del Sistema Nacional de Salud y la de los centros concerta dos segui-

\footnotetext{
58 Parece que el legislador ha asumido que el régimen de responsabilidad administrativa es consustancial a la Administración como sujeto, evidenciando una concepción subjetiva u orgánica de los servicios públicos. Si la Ley 30/1992, tras la reforma de 1999, ha unificado el régimen de responsabilidad de las Administraciones públicas cualquiera que sea la naturaleza de la actividad, pública o priva$\mathrm{da}$, no cabe duda de la vuelta del predominio legal de las concepciones estatutarias de las instituciones administrativas. En esta misma línea se sitúa también el artículo 97 del TRLCAP, al marginar del régimen administrativo de responsabilidad extracontractual a los sujetos privados que contratan con la Administración. Con ello, se habría vuelto de nuevo, en relación a los contratistas, a la situación anterior a la LEF. Ahora bien, no debemos olvidar que en esta misma materia -contratación pública-, el TJUE viene realizando una interpretación completamente distinta. El Tribunal europeo aplica un concepto funcional de poder público para sujetar a las unidades desmembradas de la Administración a la normativa contractual pública. Ejemplo de ello son las Sentencias de 16 de octubre y de 15 de mayo de 2003, Asunto C-214/00, Comisión/España, y el comentario que sobre la última realiza el profesor E. GARCÍA DE ENTERRÍA, «El tribunal de Justicia de las Comunidades Europeas constata y censura dos graves quiebras de nuestro Derecho Administrativo en materia de entes sujetos al Derecho público y de medidas cautelares contencioso-administrativas», REDA, n. ${ }^{\circ} 119,2003$, pp. 471 a 487.
} 
rá una tramitación administrativa correspondiendo su revisión jurisdiccional al orden contencioso-administrativo en todo caso.

Así pues, de los preceptos comentados se deduce claramente que las reclamaciones por responsabilidad de la Administración, sea cual sea la naturaleza de la actividad o la relación de la que emane (pública o privada), se dirigirán directamente a la propia Administración (no a su personal o agentes) y su revisión jurisdiccional corresponderá en todo caso al orden contenciosoadministrativo. Por el contrario, si la responsabilidad es imputable al contratista que gestiona una actividad de carácter público competencia de una Administración pública se sustanciará conforme a las reglas del Derecho civil y los conflictos que se susciten los conocerá también la jurisdicción civil.

Como vemos, la unificación jurisdiccional a favor del orden contencioso-administrativo ha quedado asentada para todas las pretensiones referidas a la responsabilidad patrimonial de la Administración pública, de sus autoridades y la del personal a su servicio (artículos 9.4 LOPJ, 2.e LJCA, y 139 y ss. Ley 30/1992), no así la responsabilidad del contratista cuando responde de los daños causados en la ejecución del contrato que deberá residenciarse en la jurisdicción civil. Excepto cuando el contratista sea un centro sanitario concertado en materia de asistencia sanitaria en el que la reclamación seguirá un procedimiento administrativo y su revisión corresponderá en todo caso a la jurisdicción contencioso-administrativa.

\section{LOS CONTRATOS DE SEGURO Y LA RESPONSABILIDAD PATRIMONIAL DE LA ADMINISTRACIÓN PÚBLICA}

Debido a la similitud con el objeto de estudio de este trabajo he considerado conveniente hacer una breve referencia a algunas de las cuestiones suscitadas en la aplicación de la responsabilidad patrimonial de la Administración cuando suscribe un contrato de seguro privado para cubrir el riesgo en la prestación de sus servicios ${ }^{59}$. Entre el tercero dañado y la Administración

\footnotetext{
${ }^{59}$ Véanse M. A. OrRIols SAlLeS, «Un paso atrás en el principio de unidad jurisdiccional en materia de responsabilidad de la Administración como consecuencia de la presencia de compañías aseguradoras en el proceso», Diario la Ley, n. ${ }^{\circ}$ 5720, de 17 de febrero de 2003, pp. 1 a 5; E. GAMERO CASADO, «Los contratos de seguro de responsabilidad extracontractual de las Administraciones públicas», REDA, n. ${ }^{\circ}$ 103, 1999, pp. 357-381; M.J. MONTORO CHINER, «El aseguramiento de la responsabilidad patrimonial de las Administraciones públicas», en Actas de las III Jornadas de órganos asesores y consultivos, Generalitat de Catalunya, Barcelona, 2001, pp. 95 a 116.; M.J. MonTORo Chiner y M.C. Hill Prados, Responsabilidad patrimonial de la Administración y contrato de seguro, Atelier, Barcelona, 2002.
} 
titular del servicio se interpone un sujeto de carácter privado que produce algunas disfuncionalidades en la aplicación del régimen jurídico general.

Los contratos de seguros que cubren los daños derivados tanto de relaciones jurídico-privadas de la Administración como del ejercicio de actividades administrativas son, en la actualidad, una práctica frecuente por parte de las Administraciones públicas ${ }^{60}$. Sin embargo, estos contratos no cuentan con una regulación específica que introduzca peculiaridades en el régimen de responsabilidad patrimonial de la Administración, y los problemas surgidos en torno a los mismos responden a las dificultades de compatibilizar la regulación de la responsabilidad de la Administración contenida en los artículos 139 y siguientes de la Ley 30/1992 y la LCS.

Las cuestiones que han suscitado mayores problemas son las siguientes:

La LCS configura a favor del perjudicado y de sus herederos una acción directa contra la compañía aseguradora para exigirle el cumplimiento de la obligación de indemnizar. Esa acción por determinación expresa del artículo $76^{61}$ se sustanciará en la jurisdicción civil que es el orden competente para pronunciarse sobre la existencia de esa responsabilidad -si queda cubierta o no por la póliza de seguros y sobre la cuantía indemnizatoria en su caso-. Sin embargo, conforme a la Ley 30/92 la responsabilidad de la Administración, la de sus funcionarios, autoridades y personal a su servicio por los daños causados a terceros como consecuencia del funcionamiento de los servicios públicos, es una responsabilidad directa, por lo que el particular dañado deberá dirigirse directamente a la Administración ${ }^{62}$.

\footnotetext{
${ }^{60}$ Se ha discutido mucho acerca de la naturaleza jurídica de este tipo de contratos pero hoy esta cuestión ha quedado resuelta por la determinación legal de considerarlos contratos privados (artículos 5.2.a y 3 TRLCAP), que se regirán por la normativa contractual pública únicamente en los actos de preparación y adjudicación (artículo 9 TRLCAP) y sus efectos y extinción se regularán por las normas de Derecho civil, y el orden jurisdiccional civil será también el competente para resolver las controversias que surjan entre las partes, salvo que se produzcan en relación a los actos de preparación y adjudicación (actos jurídicos separables), en cuyo caso la impugnación podrá ser en el orden contencioso-administrativo.

${ }^{61} \mathrm{El}$ artículo 76 LCS dispone que «El perjudicado o su heredero tendrán acción directa contra el asegurador para exigirle el cumplimiento de la obligación de indemnizar, sin perjuicio del derecho del asegurador a repetir contra el asegurado, en el caso de que sea debido a conducta dolosa de éste, el daño o perjuicio causado a tercero. La acción directa es inmune a las excepciones que puedan corresponder al asegurador contra el asegurado. El asegurador puede, no obstante, oponer la culpa exclusiva del perjudicado y las excepciones personales que tenga contra éste. A los efectos del ejercicio de la acción directa, el asegurado estará obligado a manifestar al tercero perjudicado o a sus herederos la existencia del contrato de seguro y su contenido».

${ }^{62}$ Por esta razón la Dirección General de Seguros mantuvo en la Resolución de 26 de junio de 1996 la imposibilidad de suscribir contratos privados de seguros sobre responsabilidad patrimonial de la Administración, dadas las incompatibilidades insalvables entre la LCS y la Ley 30/92. La DGS manifesta en la mencionada resolución que en tanto no exista una regulación normativa específica
} 
Generalmente la jurisdicción civil no ha considerado que los contratos de seguros suscritos por la Administración plantearan problema alguno de legalidad ni que el particular tuviera que reclamar necesariamente a través del procedimiento administrativo específico de responsabilidad patrimonial y ha venido conociendo de las acciones civiles directas de los particulares frente a las compañías aseguradoras ${ }^{63}$. La doctrina administrativista por su parte ha venido reclamando la aplicación específica de la responsabilidad patrimonial de la Administración admitiendo la posibilidad de interponer por parte de los particulares dañados una acción civil frente a las compañías aseguradoras pero reconociendo que la Administración deberá pronunciarse previamente sobre la existencia de responsabilidades en el procedimiento administrativo correspondiente.

Esta última postura coincide con una interpretación más acorde a la responsabilidad extracontractual de la Administración y supone entender que el tercero perjudicado por el funcionamiento del servicio público deberá dirigir su pretensión directamente a la Administración titular que será la responsable de pagar la indemnización, aunque haya suscrito un contrato de seguro para cubrir los riesgos que el servicio ocasione. Ante el particular dañado la Administración es, ex lege, la única y directa responsable, aunque posteriormente pueda entablar con la compañía aseguradora las acciones convenientes para resarcir sus derechos ${ }^{64}$. Esta ha sido la solución arbitrada por la Ley Orgánica 19/2003, de 23 de diciembre, que ha dado una nueva redacción al artículo 9.4 de la LOPJ al atribuir a la jurisdicción contencio-

\footnotetext{
de este tipo de contratos, las Administraciones públicas no podrán suscribirlos. El texto de esta resolución está publicado en la Revista de Derecho de los Seguros Privados, mayo-junio de 1997, pp. 28 y ss. Ahora bien, lo cierto es que algunas leyes sectoriales obligan a los sujetos que caen bajo su ámbito de actuación, incluidas las Administraciones públicas, a asegurarse (por ejemplo, el seguro obligatorio de vehículos de motor) y todas las Administraciones recurren a dicha práctica ya sea en los supuestos obligatorios, ya sea de forma voluntaria.

${ }^{63}$ La STS de 31 de octubre de 2003 (Sala Primera) declara que la Sala de Conflictos de Competencia del Tribunal Supremo ya se pronunció en el Auto de 10 de diciembre de 2001, manteniendo la tradicional y clásica doctrina de la vis atractiva de la jurisdicción civil reconocida en el artículo 9.2 de la LOPJ, pues, de lo contrario se obligaría al perjudicado a entablar dos procesos distintos ante dos jurisdicciones diferentes, con el riesgo de resoluciones no acordes, lo que provocaría una merma de las garantías del ciudadano y, en último término, un debilitamiento de su derecho constitucional a la tutela efectiva. Véanse también las SSTS (Sala civil) de 15 de julio de 2003, 24 de abril de 2003 y 2 de diciembre de 2002.

${ }^{64}$ Conforme a esta interpretación habría que mantener que en caso de lesión el particular debe dirigirse necesariamente a la Administración que deberá resolver el procedimiento y pagar la indemnización y posteriormente reclamaría a la compañía aseguradora el reintegro de la cantidad cubierta por la póliza. Como el acto que resuelve el procedimiento de responsabilidad afecta a la compañía aseguradora, ésta podría personarse en el procedimiento administrativo como interesada. Véase la reforma del artículo 9.4 LOPJ y del artículo 2. e) de la LJCA llevada a cabo por la Ley Orgánica 19/2003, de 23 de diciembre.
} 
so-administrativa el conocimiento de las reclamaciones de responsabilidad cuando el interesado accione directamente contra la compañía aseguradora de la Administración, junto a la Administración respectiva.

Por otra parte, la Ley 30/1992 confiere a la Administración una acción de regreso frente a sus autoridades y personal a su servicio para hacer efectivos los daños que éstos ocasionen a terceros con dolo o culpa grave, y esa acción de regreso, tras la reforma de la Ley 4/1999, es obligatoria (de carácter imperativo) para la Administración que deberá iniciar de oficio un procedimiento administrativo específico con esa finalidad. Sin embargo, la LCS (artículo 43) otorga a la compañía aseguradora (de forma facultativa) la posibilidad de subrogarse en los derechos y acciones que correspondan al asegurado frente a las personas que produciendo un daño hayan actuado dolosamente. La subrogación de la compañía aseguradora sólo se prevé, por tanto, en caso de actuación dolosa de la persona que ocasionó el daño, no por una actuación culposa grave. La Administración, sin embargo, según la Ley 30/1992 (artículo 145.2) debe llevar a cabo la acción de regreso también en caso de culpa o negligencia graves de los funcionarios, autoridades y personal a su servicio. Cabría entender entonces que puesto que la indemnización ha sido cubierta por la compañía aseguradora, la Administración no podría repercutir la cantidad al funcionario que hubiera actuado con culpa grave. En este caso, el funcionario que hubiera obrado culposamente se encontraría en una situación de impunidad carente de toda justificación y supondría una manifiesta desigualdad respecto del funcionario cuya Administración no haya asegurado sus servicios. Por ello, lo lógico sería entender que puesto que la Administración viene obligada a ejercitar la acción de regreso frente a los funcionarios que hubieran obrado de forma dolosa o culposa, la compañía aseguradora podría instar a la Administración para que de oficio reclamara al funcionario que hubiese actuado con culpa grave la indemnización pagada y en caso de inactividad de la Administración demandara a ésta ante la jurisdicción contencioso-administrativa.

Como vemos, a pesar de la reforma llevada a cabo por la Ley Orgánica 19/2003 en la responsabilidad patrimonial de la Administración cuando suscribe un contrato de seguro privado, todavía existen algunas dificultades de encaje entre la LCS y la Ley 30/1992.

\section{CONCLUSIONES}

$1^{\text {a) }}$ La legislación no ha resuelto expresamente el problema de si la responsabilidad de los concesionarios o contratistas se rige, en cuanto al fondo, por el Código Civil o por la legislación administrativa. La aplicación a los 
contratistas y concesionarios del régimen específico de responsabilidad patrimonial de la Administración, que tras la nueva redacción del artículo 141.1 de la Ley $30 / 1992$ no será siempre tan objetiva ${ }^{65}$, no encuentra respaldo alguno en ningún precepto de la legislación vigente. Sólo puede apoyarse bajo la consideración del contratista como delegado o agente de la Administración Pública que gestiona actividades de carácter público de la competencia de ésta, o en una interpretación basada en la igualdad de los administrados respecto a la garantía patrimonial que proporciona el artículo 106.2 CE frente a los daños ocasionados por el funcionamiento de los servicios públicos. Pero, al margen de que puedan compartirse o no estos argumentos, no parece que ninguno de ellos tenga encaje legal para permitirnos afirmar con carácter general que la responsabilidad extracontractual del contratista haya de regirse necesariamente por la legislación prevista para la Administración pública. No obstante, si los daños se producen como consecuencia de la prestación de asistencia sanitaria gestionada por una empresa privada a través de un contrato administrativo de gestión de servicio público como es el concierto de servicios públicos, el particular podrá exigir la responsabilidad del contratista conforme a las reglas y trámites especiales de la responsabilidad patrimonial de la Administración y en caso de conflicto conocerá en todo caso la jurisdicción contencioso-administrativa. Como vemos, el tratamiento no puede ser más dispar.

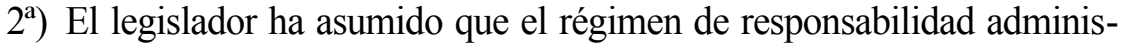
trativa es consustancial a la Administración pública como sujeto, evidenciando una concepción subjetiva u orgánica de los servicios públicos. En esta línea se sitúa el artículo 97 del TRLCAP al marginar del régimen administrativo de responsabilidad extracontractual a los sujetos privados que contratan con la Administración la gestión de actividades de carácter público y de naturaleza administrativa. Con ello se vuelve de nuevo a la situación anterior a la LEF de 1954. Y todo ello sucede en una materia a la que el TJUE viene sujetando cada vez con mayor rigor y precisión a principios jurídico-públicos ${ }^{66}$.

\footnotetext{
${ }^{65}$ El artículo 141.1 de la Ley 30/92 concreta como un supuesto de fuerza mayor que no da lugar a indemnización los daños derivados de hechos imprevisibles o inevitables según el estado de los conocimientos de la ciencia o de la técnica existentes en el momento de la producción, sin perjuicio, de las eventuales prestaciones asistenciales. Tal como especifica el profesor MARTín REBOLLO «la singularización de este supuesto trata de salir al paso de las indemnizaciones que en vía de responsabilidad se han producido a favor de personas que resultaron infectadas por el VIH a consecuencia de transfusiones llevadas a cabo en hospitales públicos antes de que se conociera la existencia del virus y de la subsiguiente enfermedad y, por lo tanto, antes de que existieran controles previos a dichas transfusiones» (Leyes Administrativas, Aranzadi, Pamplona, 2004, p. 533). Véanse sobre este tema las SSTS de 4 de octubre de 2004 (Sala 3 ${ }^{\mathrm{a}}$, R-5109/2000) y 12 de enero de 2005 (Sala 3 ${ }^{\mathrm{a}} \mathrm{R}-6718 / 2000$ ).

${ }^{66}$ El Tribunal europeo viene aplicando un concepto funcional de poder público para sujetar a las unidades desmembradas de la Administración a la normativa contractual pública. Véanse las sentencias del TJUE citadas en la nota número 35.
} 
$3^{\text {a) }}$ El procedimiento para decidir sobre la responsabilidad del contratista o concesionarios ha dejado de corresponder a la Administración pública. Lo único que se dispone ahora es que ante la dificultad que puede representar para el particular dañado dilucidar si la responsabilidad del daño corresponde al contratista o a la Administración, puede dirigir una consulta sobre este aspecto a la Administración que responderá pronunciándose exclusivamente sobre quién considera responsable del daño. Una opinión que no obliga al particular, ni al contratista, ni a los tribunales que finalmente deban pronunciarse al respecto, ni siquiera al órgano administrativo competente para resolver el procedimiento de responsabilidad que se inicie solicitando la indemnización por daños. Si tenemos en cuenta que el procedimiento establecido en el RRP únicamente contempla su aplicación a los supuestos en que la Administración es responsable, debemos concluir que ahora la reclamación de responsabilidad del contratista no se encuentra en la normativa administrativa. Se ha detraído de la esfera de la Administración la atribución de determinar la responsabilidad del contratista frente al tercero. Lo único que se prevé ahora es un requerimiento previo y opcional a la Administración contratante para que se pronuncie sobre quién es el responsable.

$\left.4^{a}\right)$ La facultad de requerir al órgano de contratación que se pronuncie sobre a cuál de las partes (Administración o contratista) corresponde la responsabilidad interrumpe el plazo de prescripción de la acción de reclamación. Acción que será diferente si se dirige contra la Administración o contra el contratista. Efectivamente, la acción habrá de ser civil si la reclamación se dirige exclusivamente frente al contratista y administrativa si se dirige frente a la Administración o frente al contratista y la Administración. Hoy no es posible en modo alguno demandar conjuntamente a la Administración y al contratista en vía civil pues lo impide claramente la LJCA de 1998 al disponer que la Administración no será demandada ante el orden civil por asuntos de responsabilidad patrimonial. Y la demanda conjunta frente al contratista y la Administración en vía contenciosoadministrativa procederá cuando el contratista hubiera concurrido junto a la Administración en la producción del daño o cuando se dirija, además, contra las personas o entidades públicas o privadas indirectamente responsables de aquélla (artículo 9.4 LOPJ) ${ }^{67}$. Como vemos, la regla general sigue siendo todavía que si la causa generadora del daño es imputable exclusivamente a la actuación del contratista será la jurisdicción civil la

\footnotetext{
${ }^{67}$ Véase la nueva redacción del artículo 9.4 de la LOPJ introducida por la Ley Orgánica 19/2003 de 23 de diciembre donde se atribuye también a la jurisdicción contencioso-administrativa el conocimiento de las demandas de responsabilidad patrimonial si se dirigen, además, contra las personas o entidades públicas o privadas indirectamente responsables de la Administración.
} 
competente para conocer los litigios que se susciten en relación con la responsabilidad extracontractual de los contratistas.

Por último, en caso de insolvencia del contratista debe afirmarse la responsabilidad subsidiaria de la Administración, lo que puede justificarse bien en la existencia de una culpa «in eligiendo» o «in vigilando» o en el riesgo creado por la propia Administración al optar por una gestión indirecta $^{68}$.

68 Vid. S. MuÑoz Machado, La responsabilidad civil concurrente de las Administraciones públicas, Civitas, Madrid, 1992, p. 135 y M. BELADIEz RoJo, Responsabilidad e imputación de daños por el funcionamiento de los servicios públicos, Tecnos, Madrid, 1997, p. 209. 